Hari/Tanggal : Kamis/5 September 2019

Tugas Pribadi :1

Kelompok :1

MAKALAH

PENGEMBANGAN BAHAN AJAR FISIKA

"Pengertian, Jenis-jenis, dan Karakteristik Bahan Ajar Cetak Meliputi Hand Out, Modul, Buku (Diktat, Buku Ajar, Buku Teks),

LKS dan Pamflet"

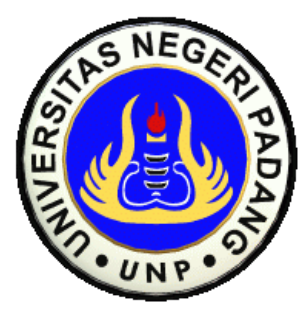

Oleh:

\title{
YURI YANTI
}

$19175020 / 2019$

Anggota Kelompok

1. Rahmi Laila (19175013)

2. Yolly Saitri (19175017)

3. Yonira Mike V.M (191718)

DOSEN PEMBIMBING:

Prof. Dr. Festiyed, M.S

Dr. Asrizal, M.Si

PROGRAM STUDI MAGISTER PENDIDIKAN FISIKA

FAKULTAS MATEMATIKA DAN ILMU PENGETAHUAN ALAM

UNIVERSITAS NEGERI PADANG 


\section{KATA PENGANTAR}

Puji dan syukur penulis ucapkan kepada Allah SWT atas limpahan rahmat, hidayah dan inayah-Nya penulis dapat menyelesaikan makalah yang berjudul "Pengertian, Jenis-jenis, dan Karakteristik Bahan Ajar Cetak Meliputi Hand Out, Modul, Buku (Diktat, Buku Ajar, Buku Teks), LKS dan Pamflet”. Sholawat beriring salam penulis sampaikan kepada nabi Muhammad SAW karena beliau telah membawa kita dari alam yang penuh dengan kejahilan menuju alam yang penuh dengan keimanan seperti yang kita rasakan sekarang ini.

Makalah ini disusun dengan tujuan untuk memenuhi tugas mata kuliah Pengembangan Bahan Ajar dan untuk menambah pengetahuan penulis tentang pengertian, jenis-jenis, karakteristik bahan ajar cetak meliputi hand out, modul, buku (diktat, buku ajar, buku teks), LKS dan pamflet. Dengan adanya makalah ini penulis berharap dapat membantu teman-teman dalam mata kuliah Pengembangan Bahan Ajar Fisika.

Dalam penyelesaian makalah ini penulis banyak menemui kendala. Namun berkat bantuan dari berbagai pihak, penulis dapat menyelesaikan makalah ini dengan baik. Oleh karena itu, penulis mengucapkan terima kasih kepada semua pihak yang telah membantu khususnya dosen pembimbing mata kuliah Pengembangan Bahan Ajar Fisika, Ibu Prof. Dr. Hj. Festiyed, M.S dan Bapak Dr.Asrizal, M.Si

Penulis menyadari dalam penyajian makalah ini masih terdapat banyak kekurangan. Untuk itu, penulis mengharapkan saran dari pembaca, agar penulis dapat memperbaiki kesalahan tersebut pada pembuatan makalah selanjutnya. Akhir kata, semoga makalah ini bermanfaat sebagaimana yang diharapkan. Amin.

Padang, 2 September 2019

Penulis 


\section{DAFTAR ISI}

KATA PENGANTAR ........................................................................... $\mathrm{i}$

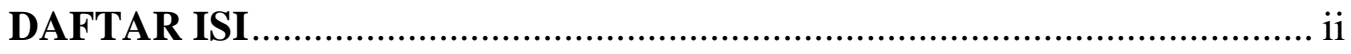

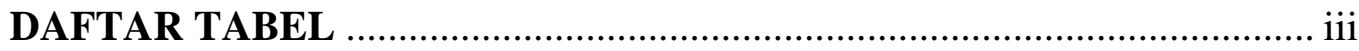

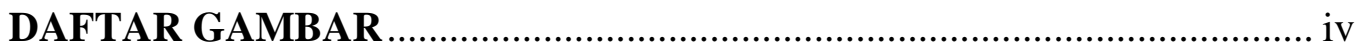

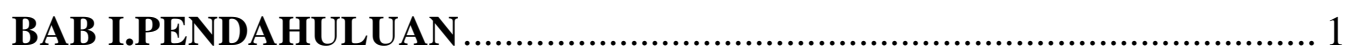

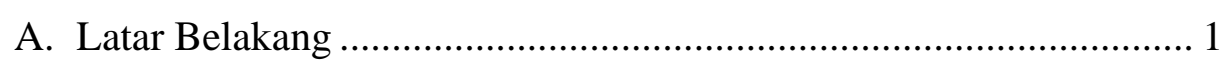

B. Rumusan Masalah ...................................................................... 2

C. Tujuan Penulisan .......................................................................... 2

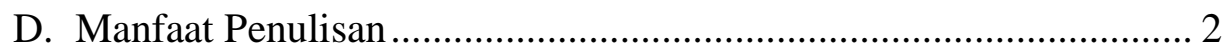

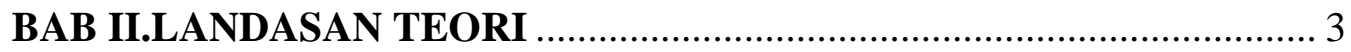

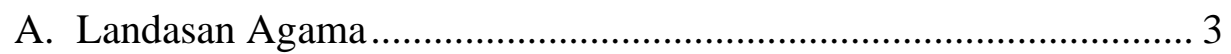

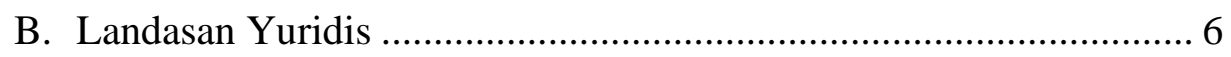

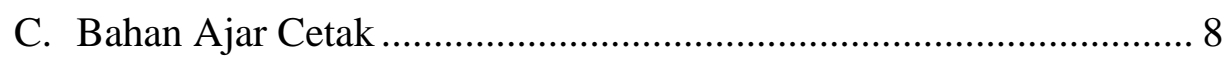

D. Karakteristik Bahan Ajar Cetak ................................................... 11

E. Jenis-Jenis Bahan Ajar Cetak ...................................................... 11

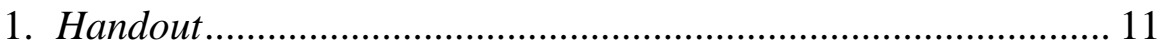

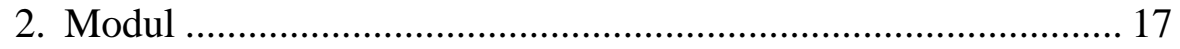

3. Buku (Diktat, Buku Ajar, Buku Teks)....................................... 25

4. Lembar Kerja Siswa (LKS) ................................................... 33

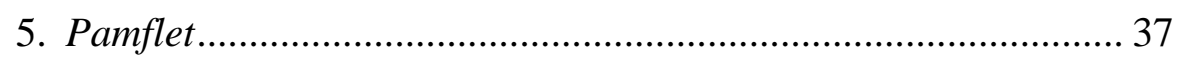

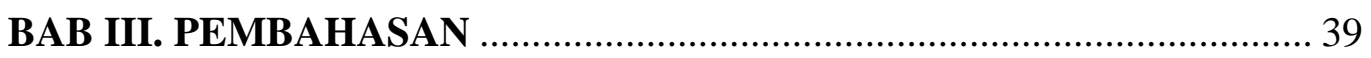

A. Matriks Perbedaan Bahan Ajar Cetak ............................................... 39

B. Matriks Kelebihan dan Kekurangan Bahan Ajar Cetak................... 41

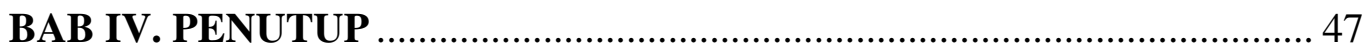

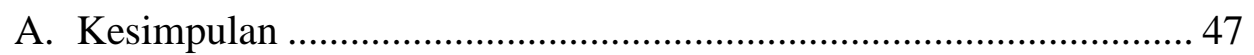

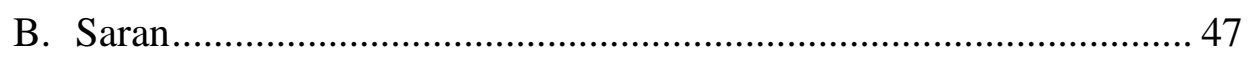

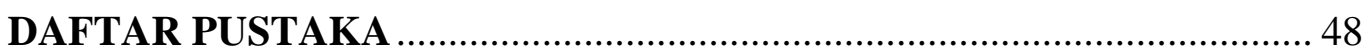




\section{DAFTAR TABEL}

Tabel 1. Matrik Perbedaan Bahan Ajar Cetak 39

Tabel 2. Kelebihan dan Kekurangan Bahan Ajar Cetak .................................... 41 


\section{DAFTAR GAMBAR}

Gambar 1. Contoh Handout Gaya dan Macam-Macam Gaya.......................... 17

Gambar 2. Contoh Modul Fisika SMA........................................................... 25

Gambar 3. Contoh Diktat Fisika Dasar.......................................................... 28

Gambar 4. Contoh Buku Ajar IPA Terpadu kelas VIII SMP ............................ 30

Gambar 5. Contoh Buku Teks Fisika.............................................................. 32

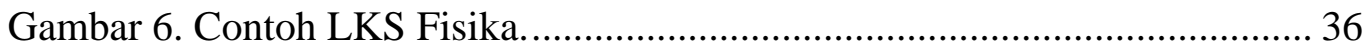

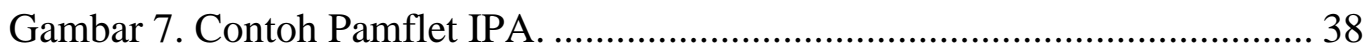




\section{BAB I \\ PENDAHULUAN}

\section{A. Latar Belakang}

Perkembangan Ilmu Pengetahuan dan Teknologi (IPTEK) sangat berperan penting dalam proses pembelajaran. Penggunaan alat bantu sangat membantu aktivitas proses belajar mengajar di kelas terutama peningkatan prestasi belajar siswa atau mahasiswa. Penggunaan media pengajaran turut menentukan keberhasilan dan meningkatkan kualitas pembelajaran. Media memiliki kekuatan positif yang mampu membuat proses pembelajaran lebih kreatif dan dinamis. Saat ini, peran media sangat dibutuhkan dalam proses pembelajaran, media bukan hanya sekedar alat bantu tetapi sudah merupakan bagian yang integral dalam sistem pendidikan dan pembelajaran. Oleh karena itu, para guru dituntut agar mampu menggunakan alat-alat yang dapat disediakan oleh sekolah, dan tidak tertutup kemungkinan bahwa alat-alat tersebut sesuai dengan perkembangan dan tuntutan zaman.

Dalam proses pembelajaran, guru membutuhkan suatu bahan ajar untuk membantu guru dalam kegiatan belajar mengajar di kelas. Pada proses belajar mengajar ini akan diperoleh suatu hasil pengajaran. Masalah yang dihadapi guru dalam kegiatan proses pembelajaran adalah memilih/menentukan materi pembelajaran atau bahan ajar yang tepat dalam rangka membantu peserta didik mencapai kompetensi yang diharapkan. Hal ini disebabkan oleh kenyataan bahwa dalam kurikulum atau silabus, materi bahan ajar hanya dituliskan secara garis besar dalam bentuk materi pokok. Tugas guru adalah menjabarkan materi pokok tersebut sehingga manjadi bahan ajar yang lengkap.

Sehubungan dengan hal tersebut perlu disusun rambu-rambu pemilihan dan pemanfaatan bahan ajar untuk membantu guru agar mampu memilih materi pembelajaran atau bahan ajar dan memanfaatkannya dengan tepat. Rambu-rambu tersebut dapat berupa konsep dan prinsip pemilihan materi pembelajaran, penentuan cakupan, urutan, kriteria, dan langkah-langkah pemilihan, pemanfaatan, serta sumber materi pembelajaran sehingga guru akan lebih mendapatkan kemudahan dalam penyampaian materi-materi pelajaran tersebut. 
Kemampuan guru dalam mengembangkan bahan ajar bisa dikembangkan, khususnya untuk mata pelajaran masing-masing, maka masalah kelangkaan bahan ajar di sekolah-sekolah dapat diatasi, karena setiap guru dapat mengembangkan bahan ajar sendiri sesuai mata pelajaran yang diampu oleh guru yang bersangkutan.

Berdasarkan masalah di atas, penulis ingin mengetahui lebih dalam mengenai pengertian, jenis-jenis, karakteristik bahan ajar cetak meliputi hand out, modul, buku (diktat, buku ajar, buku teks), LKS dan pamflet agar guru atau calon guru memiliki pedoman untuk menyusun bahan ajar yang sesuai dengan karakteristik siswa.

\section{B. Rumusan Masalah}

Berdasarkan latar belakang di atas, maka rumusan masalah pada makalah ini, yaitu:

1. Apakah pengertian dari bahan ajar cetak ?

2. Bagimana karakteristik bahan ajar cetak?

3. Apakah saja jenis-jenis bahan ajar cetak?

\section{Tujuan Penulisan}

Adapun tujuan penulisan makalah berdasarkan rumusan masalah di atas adalah sebagai berikut.

1. Mahasiswa dapat menjelaskan pengertian bahan ajar cetak.

2. Mahasiswa dapat mengetahui karakteristik bahan ajar cetak.

3. Mahasiswa dapat mengetahui jenis-jenis bahan ajar cetak

\section{Manfaat Penulisan}

Penulisan makalah ini diharapkan dapat bermanfaat untuk berbagai pihak, terutama:

1. Tenaga pendidik, sebagai tambahan wawasandan masukan dalam menyusun bahan ajar cetak.

2. Penulis, sebagai wadah untuk mengembangkan kompetensi, menambah pengetahuan mengenai bahan ajar cetak serta sebagai modal untuk menulis tesis dan melakukan penelitian ilmiah dalam pengembangan bahan ajar cetak. 


\section{BAB II \\ LANDASAN TEORI}

\section{A. Landasan Agama}

Al-Qur'an selalu menyuruh umat manusia untuk belajar membaca melalui perantara Nabi Muhammad SAW. Hal ini tercantum dalam surah Al-Alaq'. Perintah membaca dalam surat Al-Alaq' ini diulangi 2 kali. Pengulangan tersebut sebagai penegasan terhadap arti pentingnya membaca dan untuk meningkatkan minat baca dengan motivasi bahwa orang yang membaca akan mencapai derajat terpuji.

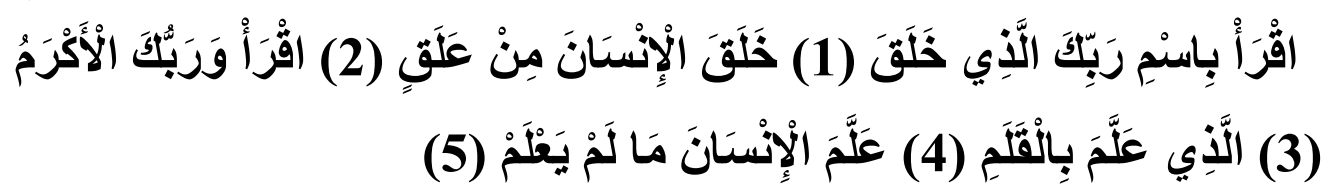

Artinya:"Bacalah dengan (menyebut) nama Tuhanmu yang menciptakan, Dia telah menciptakan manusia dari 'Alaq, Bacalah, dan Tuhanmulah yang paling Pemurah, Yang mengajar manusia dengan pena, Dia mengajarkan kepada manusia apa yang belum diketahuinya".

Dalam surah Al-Alaq' 1-5 terkandung makna bahwa Allah SWT sangat apresiatif terhadap ilmu pengetahuan. Dia memberi isyarat pentingnya manusia untuk belajar membaca dan menulis dan menganalisa segala yang ada dengan diberi potensi akal sebagai pisau pengasahnya. Dengan membaca dan menulis, manusia menjadi khalifah di bumi sebagaimana yang dijanjikan-Nya. Dengan diawali membaca, menulis dan selanjutnya mengetahui jagat raya dan dibalik semuanya, kemudian manusia beriman, di sinilah baru nampak kedudukan manusia yang tinggi,

Pada dasarnya konsep belajar itu selalu menunjukkan kepada suatu proses perubahan perilaku atau pribadi seseorang berdasarkan praktek atau pengalaman tertentu. Hal-hal ini dapat terlaksana dengan baik atas ketersediaan bahan ajar yang baik sehingga materi-materi yang diajarkan dapat tersampaikan dengan benar. Hal ini sejalan dengan Firman Allah dalam Al-Qur'an Al-Maidah ayat 46 : 


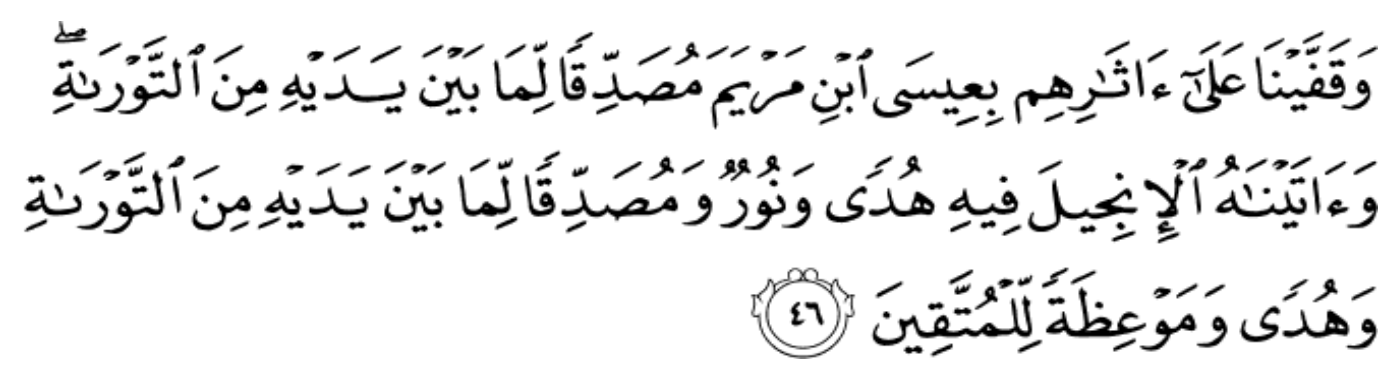

Artinya :"Dan Kami iringkan jejak mereka (nabi nabi Bani Israil) dengan Isa putera Maryam, membenarkan Kitab yang sebelumnya, yaitu: Taurat. Dan Kami telah memberikan kepadanya Kitab Injil sedang didalamnya (ada) petunjuk dan dan cahaya (yang menerangi), dan membenarkan kitab yang sebelumnya, yaitu Kitab Taurat. Dan menjadi petunjuk serta pengajaran untuk orang-orang yang bertakwa”.

Berdasarkan Q.S Al-maidah ayat 46 diketahui bahwa Al-Qur'an diturunkan untuk menyempurnakan kitab-kitab sebelumnya. Al-Qur'an berisi petunjuk dan pedoman bagi umat manusia. Begitu juga dalam pengembangan bahan ajar, baik cetak maupun non cetak diharapkan mampu menjadi pedoman bagi siswa dalam melaksanakan pembelajaran. Bahan ajar yang baik mencantumkan petunjuk belajar bagi siswa dan disampaikan dengan bahasa yang mudah dimengerti oleh siswa.

Q.S Al-Nahl Ayat 78 yang berbunyi :

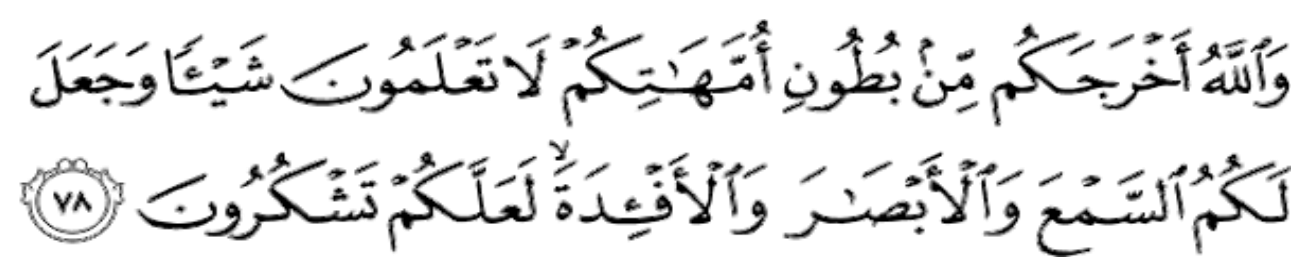

Artinya : Dan Allah mengeluarkan kamu dari perut ibumu dalam keadaan tidak mengetahui sesuatupun, dan Dia memberi kamu pendengaran, penglihatan dan hati, agar kamu bersyukur.

Q.S Al-Isra' Ayat 36 yang berbunyi :

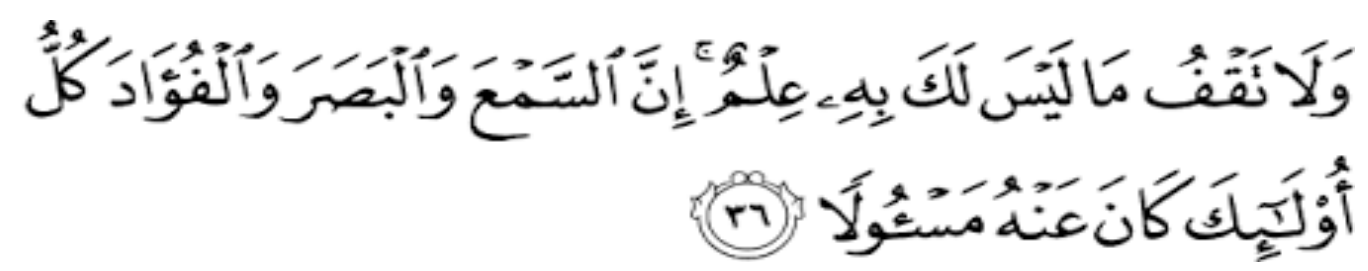


Artinya : Dan janganlah kamu mengikuti apa yang kamu tidak mempunyai pengetahuan tentangnya. Sesungguhnya pendengaran, penglihatan dan hati, semuanya itu akan diminta pertanggungan jawabnya.

Q.S As-Sajdah ayat 9 yang berbunyi :

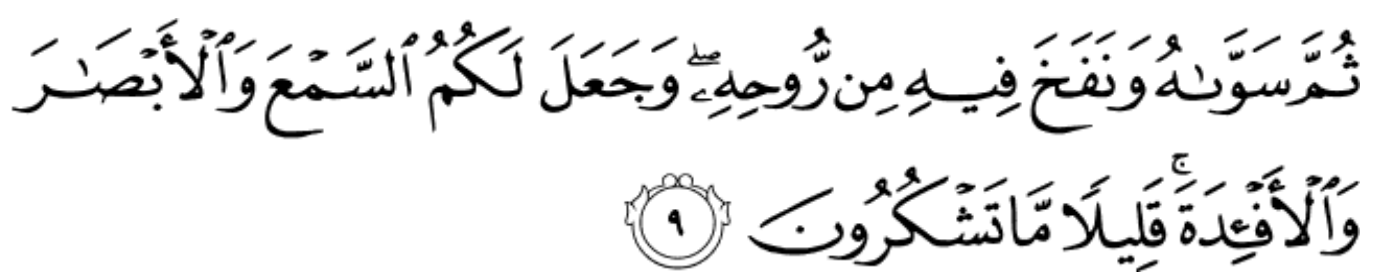

Artinya : Kemudian Dia menyempurnakan dan meniupkan ke dalam (tubuh) nya roh (ciptaan)-Nya dan Dia menjadikan bagi kamu pendengaran, penglihatan dan hati; (tetapi) kamu sedikit sekali bersyukur.

Q.S. Al-Ahqaf ayat 26:

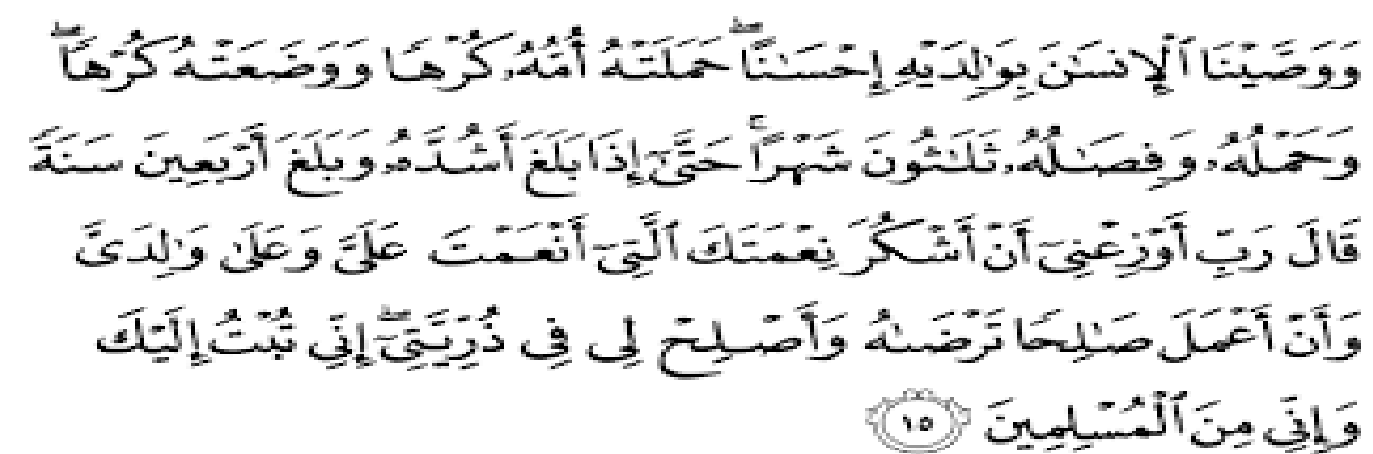

Artinya : Dan sesungguhnya Kami telah meneguhkan kedudukan mereka dalam hal-hal yang Kami belum pernah meneguhkan kedudukanmu dalam hal itu dan Kami telah memberikan kepada mereka pendengaran, penglihatan dan hati; tetapi pendengaran, penglihatan dan hati mereka itu tidak berguna sedikit juapun bagi mereka, karena mereka selalu mengingkari ayat-ayat Allah dan mereka telah diliputi oleh siksa yang dahulu selalu mereka memperolok-olokkannya.

Dengan adanya bahan ajar di dalam pembelajaran dapat dijadikan sebagai sumber atau sarana pendukung dalam pembelajaran sehingga adanya peningkatan pengetahuan yang dimiliki oleh guru dan siswa. Begitu juga Al Qur'an, yang dapat digunakan untuk menambah pengetahuan. Hal ini sesuai dengan Firman Allah dalam Surat Thoha ayat 114: 


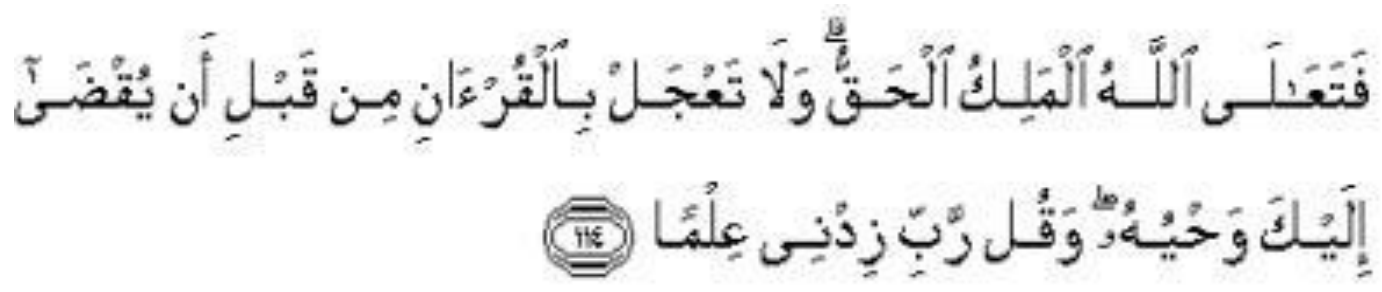

Artinya:"Maka Maha Tinggi Allah Raja Yang sebenar-benarnya, dan jangnlah kamu tergesa-gesa mambaca Al qur'an sebelum di sempurnakan mewahyukannya kepadamu, dan katakanlah:" Ya Tuhanku, tambahkanlah kepadu ilmu pengetahuan" (Q.S Thoha:114)

Hal ini senanda dalam Q.S Shod ayat 29 tentang memperhatikan ayat-ayat $\mathrm{Al}$ qur'an agar mendapat pelajaran yang berbunyi:

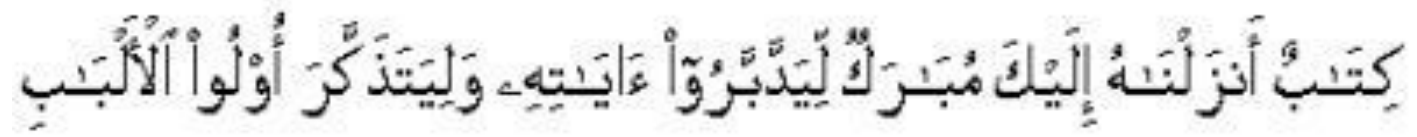

Artinya: "Ini adalah sebauh kitab yang kami turunkan kepadamu penuh dengan keberkahan supaya mereka memperhatikan ayat-ayatnya, dan supaya mendapatkan pelajaran orang-orang yang mempunyai pikiran”.

Dalam beberapa ayat Al-Qur'an ini kita dapat mengetahui bahwa Allah telah menjadikan kita dapat mendengar dan melihat. Jika kita mendengar dan melihat hal-hal yang baik dan tentang kebaikan, maka kita bisa menjadikan apa yang kita dengar itu sebagai ilmu sehingga untuk menyampaikan pelajaran pun telah dibuat bahan ajar yang dapat mendukung proses pembelajaran.

\section{B. Landasan Yuridis}

Undang-Undang Nomor 20 Tahun 2003 tentang Sistem Pendidikan Nasional, Pasal 1 angka 1 menyatakan bahwa pendidikan adalah usaha sadar dan terencana untuk mewujudkan suasana belajar dan proses pembelajaran agar peserta didik secara aktif mengembangkan potensi dirinya untuk memiliki kekuatan spiritual keagamaan, pengendalian diri, kepribadian, kecerdasan, akhlak mulia, serta keterampilan yang diperlukan dirinya, masyarakat, bangsa dan negara.

Pembelajaran adalah suatu proses yang dapat mengembangkan seluruh potensi siswa. Menurut Festiyed (2015:160) menyatakan bahwa pembelajaran 
dalam kurikulum 2013 harus dilakukan dalam pola yang terintegrasi. Salah satu tugas guru dalam proses pembelajaran adalah mengkondisikan lingkungan agar menunjang terjadinya perubahan perilaku bagi peserta didik dengan menggunakan bahan ajar yang sesuai

Bahan ajar merupakan seperangkat materi/substansi pembelajaran (teaching material) yang disusun secara sistematis, menampilkan sosok utuh dari kompetensi yang akan dikuasai siswa dalam kegiatan pembelajaran. Menurut Depdiknas (2008:11) mengungkapkan pengembangan bahan ajar hendaknya memperhatikan prinsip-prinsip bahan ajar berikut: (1) mulai dari yang mudah untuk memahami yang sulit, dari yang konkret untuk memahami yang abstrak; (2) pengulangan memperkuat pemahaman; (3) umpan balik positif memberikan penguatan terhadap pemahaman siswa; (4) motivasi yang tinggi merupakan salah satu faktor penentu keberhasilan belajar; (5) mencapai tujuan; (6) mengetahui hasil yang dicapai. Selanjutnya Kemendiknas 2010 menyatakan bahwa bahan ajar cetak dikembangkan memberikan kontribusi positif dalam hal : (1) membantu terjadinya proses pembelajaran dan pengembangan kompetensi (2) memberikan pengalaman yang nyata dan real (3) memotivasi adanya tindakan (action).

Di samping itu, Peraturan Pemerintah Nomor 32 tahun 2013 tentang perubahan atas Peraturan Pemerintah Nomor 19 tahun 2005 tentang Standar Nasional Pendidikan dalam pasal 19 ayat 1 menyatakan bahwa proses pembelajaran pada satuan pendidikan diselenggarakan secara interaktif, inspiratif, menyenangkan, menantang, memotivasi peserta didik untuk berpartisipasi aktif, serta memberikan ruang yang cukup bagi prakarsa, kreativitas dan kemandirian sesuai bakat, minat dan perkembangan fisik serta psikologi peserta didik.

Berdasarkan Permendikbud nomor 8 tahun 2016 dinyatakan bahwa :

1. Buku yang digunakan oleh satuan pendidikan terdiri atas buku teks pelajaran dan buku non teks pelajaran

2. Buku yang digunakan oleh satuan pendidikan wajib memenuhi nilai/norma positif yang berlaku di masyarakat

3. Buku yang digunakan oleh satuan pendidikan wajib mengandung kriteria penilaian sebagai buku yang layak digunakan oleh satuan pendidikan. 
Dari penjelasan di atas diketahui bahwa untuk mewujudkan tujuan pendidikan nasional guru sebagai fasilitator harus inovatif dalam proses pembelajaran. Selain itu guru juga sebagai pendidik dan orang tua bagi peserta didik di sekolah (Buchori, 2015: 369). Salah satu upaya yang dilakukan adalah dengan membuat bahan ajar.

\section{Bahan Ajar Cetak}

Pada abad ke-21, siswa dituntut untuk mengembangkan kompetensi generik (kreativitas, komunikasi, pendidikan karakter, literasi dan pemikiran kritis) agar tujun pembelajarn tercapai (Festiyed,2018:2). Untuk mencapai tujuan tersebut guru harus pandai memilih bahan ajar yang tepat digunakan pada saat pembelajaran. Bahan ajar merupakan segala sesuatu yang dibutuhkan oleh guru untuk mempermudah dalam proses pembelajaran.

Pernyataan ini didukung Yezita (2012: 55) yang menyatakan bahwa "bahan ajar adalah segala bentuk bahan yang digunakan untuk membantu guru/instruktur dalam melaksanakan kegiatan pembelajaran di kelas yang disusun secara sistematis baik tertulis maupun tidak tertulis”. Bahan ajar adalah segala sesuatu yang menjadi isi kurikulum yang harus dikuasai oleh siswa sesuai dengan kompetensi dasar dalam rangka pencapaian standar kompetensi setiap mata pelajaran dalam satuan pendidikan tertentu (Sanjaya, 2008: 141). Jadi, bahan ajar adalah kumpulan dari segala bentuk bahan yang disusun secara sistematis dan digunakan dalam proses pembelajaran untuk mencapai tujuan yang diinginkan.

Menurut Winkel (2004: 330) menyatakan bahawa bahan ajar adalah bahan yang digunakan untuk belajar dan yang membantu untuk mencapai tujuan instruksional. Sedangkan menurut Umar (2002: 139) menyatakan, bahan ajar adalah bagian yang penting dalam proses belajar mengajar yang menempati kedudukan yang menentukan keberhasilan belajar mengajar yang berkaitan dengan ketercapaian tujuan pembelajaran. Bahan ajar adalah segala bentuk bahan yang digunakan untuk membantu guru/instruktur dalam melaksanakan kegiatan belajar mengajar di kelas (Nugraha,2013:28). Jadi, bahan ajar adalah informasi, alat, dan teks yang diperlukan pengajar/guru untuk perencanaan dan penelaahan 
implementasi pengajaran untuk mencapai tujuan instruksional. Bahan yang dimaksud bisa berupa bahan tertulis maupun bahan tidak tertulis.

Bahan ajar dirancang sebagai alat yang dapat membantu guru dan siswa dalam proses pembelajaran sehingga pembelajaran lebih efektif (Festiyed, 2018:444). Bahan ajar bersifat sistematis, unik dan spesifik. Bahan ajar bersifat sistematis artinya disusun secara urut sehingga memudahkan siswa belajar. Bahan ajar bersifat unik artinya bahan ajar hanya digunakan untuk sasaran tertentu dan dalam proses pembelajaran tertentu, dan bahan ajar bersifat spesifik artinya isi bahan ajar dirancang sedemikian rupa hanya untuk mencapai kompetensi tertentu dari sasaran tertentu.

Bahan ajar terdiri dari bahan ajar cetak dan non cetak. Bahan ajar cetak dapat diartikan sebagai perangkat bahan yang memuat materi atau isi pelajaran untuk mencapai tujuan pembelajaran yang dituangkan dengan menggunakan teknologi cetak. Suatu bahan ajar cetak memuat materi yang berupa ide, fakta, konsep, prinsip, kaidah atau teori yang tercakup dalam mata pelajaran sesuai dengan disiplin ilmunya serta informasi lainnya dalam pembelajaran. Sedangkan bahan ajar non cetak merupakan bahan ajar yang tidak di print atau tidak dalam bentuk kertas.

Jenis bahan ajar dibedakan atas beberapa kriteria pengelompokkan. Berdasarkan bentuknya Prastowo (2011:40) membagi bahan ajar menjadi empat macam yaitu:

1. Bahan ajar cetak (print),yakni sejumlah bahan ajar yang disiapkan dalam kertas, yang dapatberperan untuk keperluan pembelajran atau penyampaian informasi (Kemp dan Dayton 1985). Contohnya, handout, buku, modul, lembar kerja siswa, brosur, leaflet, wallchart, foto atau gambar dan model atau maket.

2. Bahan ajar dengar atau program audio,yakni semua sistem yang menggunakan sinyal radio secara langsung, yang dapat dimainkan atau didengar oleh sesorang atau sekelompok orang. Contohnya kaset, radio, piringan hitam, dan compact disk audio. 
3. Bahan ajar pandang dengar (audio visual), yakni segala sesuatu yang memungkinkan sinyal audio dapat dikombinasikan dengan gambar bergerak secara sekuensial. Contohnya video compact disk dan film.

4. Bahan ajar interaktif yakni kombinasi dari dua atau lebih bahan ajar (audio, teks, grafik, gambar, animasi, dan video) yang oleh penggunanya dimanipulasi atau diberi perlakuan untuk mengendalikan suatu perintah dan/atau perilaku alami dari suatu presentasi. Contohnya :compact disk interaction.

Menurut Rowntree dalam Prastowo (2011:42) mengatakan bahwa berdasarkan sifatnya, bahan ajar dibagi menjadi empat macam, yaitu sebagai berikut :

1. Bahan ajar yang berbasis cetak, misalnya buku, pamphlet, panduan belajar siswa, bahan tutorial, buku kerja siswa, peta, chart, foto bahan dari majalah serta Koran, dan lain sebagainya.

2. Bahan ajar yang berbasiskan teknologi, misalnya audio cassette, siaran radio, slide, filmstrips, film, video cassettes, siaran televise, video interaktif, computer based tutotial, dan multibahan ajar.

3. Bahan ajar yang digunakan untuk praktik atau proyek, misalnya kit sains, lembar observasi, lembar wawancara, dan lain sebagainya.

4. Bahan ajar yang dibutuhkan untuk keperluan interaksi manusia (terutama untuk keperluan pendidikan jarak jauh), misalnya telepon, handphone, video conferencing, dan lain sebagainya

Dari pembahasan di atas dapat diketahui bahwa terdapat berbagai jenis bahan ajar namun secara umum bisa kita bedakan menjadi dua yaitu cetak dan non cetak dimana bahan ajar non cetak terdiri dari bahan ajar audio, audio visual, dan interaktif.

Bahan ajar cetak dapat ditampilkan dalam berbagai bentuk. Jika bahan ajar cetak tersusun secara baik maka bahan ajar akan mendatangkan beberapa keuntungan, yaitu:

1. Bahan tertulis biasanya menampilkan daftar isi, sehingga memudahkan bagi seorang guru untuk menunjukkan kepada peserta didik bagian mana yang sedang dipelajari 
2. Biaya untuk pengadaannya relatif sedikit

3. Bahan tertulis cepat digunakan dan dapat dipindah-pindah secara mudah

4. Susunannya menawarkan kemudahan secara luas dan kreativitas bagi individu

5. Bahan tertulis relatif ringan dan dapat dibaca di mana saja

6. Bahan ajar yang baik akan dapat memotivasi pembaca untuk melakukan aktivitas, seperti menandai, mencatat, membuat sketsa.

7. Bahan tertulis dapat dinikmati sebagai sebuah dokumen yang bernilai besar

\section{Karakteristik Bahan Ajar Cetak}

Menurut Winkel (2004: 331), beberapa karakteristik bahan ajar, antara lain yaitu :

1. Harus mampu membelajarkan sendiri para siswa (Self Instructional)

Self Instructional adalah bahan ajar mempunyai kemampuan menjelaskan yang sejelasjelasnya untuk membantu siswa dalam proses pembelajaran, baik dalam bimbingan guru maupun secara mandiri.

2. Bersifat lengkap (self contained)

Self contained artinya memuat hal-hal yang sangat diperlukan dalam proses pembelajaran. Hal-hal tersebut adalah tujuan pembelajaran/kompetensi prasyarat yaitu materi-materi pelajaran yang mendukung, prosedur pembelajaran, materi pembelajaran yang tersusun sistematis, latihan atau tugastugas, soal-soal evaluasi beserta kunci jawaban

3. Mampu membelajarkan peserta didik (self instruction material)

Self instruction material artinya dalam bahan pelajaran cetak harus mampu memicu siswa untuk aktif dalam proses belajarnya bahkan membelajarkan siswa untuk dapat menilai kemampuan belajarnya sendiri.

\section{E. Jenis-Jenis Bahan Ajar Cetak}

\section{Handout}

\section{a. Pengertian Handout}

Guru dan siswa dapat menggunakan bahan ajar sains sebagai sumber belajar alternatif. Salah satu bahan ajar yang dapat digunakan adalah handout (Asrizal dan Festiyed, 2018: 6). Handout adalah bahan tertulis yang siapkan oleh seorang 
guru untuk memperkaya pengetahuan peserta didik, termasuk pada media ajar cetak. Handout berasal dari bahasa Inggris yang berarti informasi, berita atau surat lembaran. Handout termasuk media cetakan yang meliputi bahan-bahan yang disediakan di atas kertas untuk pengajaran dan informasi belajar, biasanya diambil dari beberapa literatur yang memiliki relevansi dengan materi yang diajarkan dan materi pokok yang harus dikuasai oleh peserta didik.

Handout adalah bahan ajar tertulis yang berisi materi secara ringkas dan dilengkapi dengan uji kompetensi untuk mengasah kemampuan siswa. Menurut Amri (2013:104), menyatakan bahwa "Di dalam dunia pendidikan, handout merujuk pada selembar (beberapa lembar) kertas yang berisi tugas atau tes yang diberikan guru kepada siswa”. Sependapat dengan Majid (2012:175) mengemukakan bahwa, "Handout adalah bahan ajar tertulis yang disiapkan oleh seorang guru untuk memperkaya pengetahuan peserta didik". Hal ini sejalan dengan penelitian yang dilakukan oleh Rizqiyah (2018:70) menyatakan bahwa peserta didik yang diberikan handout memiliki pengetahuan yang lebih tinggi dibandingkan sebelum diberikan handout. Jadi, dapat disimpulkan bahwa handout merupakan bahan ajar tulis yang telah disiapkan oleh guru berupa lembaranlembaran yang berisi tugas atau tes yang akan diberikan kepada siswa untuk menambah pengetahuan siswa.

Handout termasuk dalam media cetakan yang meliputi bahan-bahan yang disediakan di atas kertas untuk 20 pengajaran dan informasi belajar. Handout diambil dari beberapa literatur yang memiliki relevansi dengan materi yang diajarkan/kompetensi dasar dan materi pokok yang harus dikuasai oleh siswa.

Fungsi handout bagi siswa adalah:

1) Memperoleh informasi tambahan yang belum tentu mudah diperoleh secara cepat dari tempat lain.

2) Memberikan rincian prosedur atau teknik pelaksanaan yang terlalu kompleks bila menggunakan media audiovisual.

3) Materi yang terlalu panjang/kompleks yang telah diringkas dalam bentuk catatan yang mudah dipahami. 


\section{b. Jenis-Jenis Handout}

Handout dikelompokkan menjadi 2 jenis, yaitu handout yang terlepas sama sekali dari buku utamanya dan handout yang menjadi bagian tak terpisahkan dari buku atau modul yang dugunakan untuk materi tertentu. Berdasarkan karakteristik mata pelajaran, handout dibedakan menjadi 2 macam, yaitu:

1) Handout mata pelajaran praktik

Pada jenis mata pelajaran praktik susunan handoutnya memiliki ketentuan sebagai berikut.

a) Dalam materi pokok kegiatan praktik, terdiri atas langkah-langkah kegiatan atau proses yang harus dilakukan peserta didik, yakni langkah demi langkah dalam memilih, merangkai, dan menggunakan alat/instrumen yang akan digunakan atau dipasangkan dalam unit/rangkaian kegiatan praktik.

b) Pembelaran dengan menggunakan praktik ini berbeda dengan pelajaran menggunakan teori.

c) Perlu dilakukan pre test terlebih dahulu sebelum peserta didik memasuki ruangan laboratorium atau bengkel, atau mengetahui sejauh mana peserta didik telah siap dengan segala apa yang akan dilakukan dalam praktik tersebut.

d) Penggunaan alat evaluasi sangat diperlukan dan melihat tingkat ketercapaian tujuan serta kompetensi-kompetensi yang harus dikuasai dan dicapai oleh setiap peserta didik.

e) Keselamatan kerja dilaboratorium bengkel perlu dibudayakan dalam kegiatan praktik, baik dilaboratorium maupun bengkel

f) Format identitasnya sesuai dengan penjelasan sebelunmya, sedangkan isi handout disesuaikan dengan kekhususan materinya.

2) Handout Mata Pelajaran Nonpraktik

Untuk jenis mata pelajaran nonpraktik, susunan handoutnya memiliki ketentuan sebagai berikut:

a) Sebagai acuan handout adalah SAP (Satuan Acara Pembelajaran)

b) Format Handout: 
(1)Bebas (Slide, transparasi, paper based) dan dapat berbentuk kalimat tetapi singkat atau skema dan gambar.

(2)Tidak perlu memaki header atau footer untuk setiap slide, cukum halaman pertama saja yang menggunakannya.

c) Konten (isi) handout terdiri atas overview materi dan rincian materi.

\section{c. Karakteristik Handout}

Karakteristik Handout adalah:

1) Karakteristik yang harus dimiliki oleh handout adalah padat informasi dan dapat memberikan kerangka pemikiran yang lebih utuh.

2) Sebagai media pengajaran penjelasan yang lebih rinci tentang isi handout masih harus diberikan oleh guru yang mengadakan pembelajaran.

3) Handout diberikan pada awal atau sebelum pelajaran dimulai dan merupakan catatan tambahan bagi siswa.

\section{d. Bentuk Handout}

Bentuk Handout dapat bervasiasi, yaitu:

1) Bentuk catatan.

Handout ini menyajikan konsep-konsep, prinsip, gagasan pokok tentang suatu topik yang akan dibahas.

2) Bentuk diagram

Handout ini merupakan suatu bagan, sketsa atau gambar, baik yang dilukis secara lengkap maupun yang belum lengkap.

3) Bentuk catatan dan diagram

Handout ini merupakan gabungan dari bentuk pertama dan kedua

\section{e. Penyusunan Handout}

Handout disusun atas dasar kompetensi dasar yang harus dicapai oleh peserta didik. Handout biasanya merupakan bahan tertulis tambahan yang dapat memperkaya peserta didik dalam belajar untuk mencapai kompetensinya. Langkah-langkah menyusun handout adalah sebagai berikut :

1) Menentukan judul handout, disesuaikan dengan kompetensi dasar dan materi pokok yang akan dicapai. 
2) Mengumpulkan referensi sebagai bahan penulisan. Diutamakan referensi terkini dan relevan dengan materi pokoknya.

3) Menulis handout dengan kalimat yang singkat padat namun jelas.

4) Mengevaluasi hasil tulisan dengan cara dibaca ulang untuk menemukan kemungkinan kekurangan-kekurangan.

5) Menggunakan berbagai sumber belajar yang dapat memperkaya materi Handout misalnya buku, internet, majalah, dan jurnal hasil penelitian.

Pertimbangan yang perlu dilakukan dalam memilih handout adalah :

1) Substansi materi memiliki relevansi yang dekat dengan kompetensi dasar atau materi pokok yang harus dikuasai peserta didik.

2) Materi memberikan penjelasan secara lengkap tentang defenisi, klasifikasi, prosedur, perbandingan, rangkuman, dan sebagainya.

3) Padat pengetahuan.

4) Kebenaran materi dapat dipertanggung jawabkan.

5) Kalimat yang disajikan singkat dan jelas.

6) Dapat diambil dari buku atau internet.

Unsur-unsur penyusun handout adalah:

1) Standar kompetensi adalah tujuan yang dicapai siswa setelah diberi satu pokok bahasan yang berfungsi untuk memberikan pandangan umum tentang hal-hal yang dikuasai siswa.

2) Kompetensi dasar adalah tujuan yang akan dicapai setelah mengikuti pelajaran untuk 1 kali pertemuan. Fungsinya untuk memberikan fokus pada siswa pada sub pokok bahasan yang sedang dihadapi.

3) Ringkasan materi pelajaran merupakan kesimpulan-kesimpulan dari bahan ajar yang akan disampaikan atau diberikan pada siswa dan telah disusun secara sistematis.

4) Soal-soal adalah permasalahan yang harus diselesaikan siswa setelah ia menerima atau mempelajari materi pelajaran tersebut, penyelesaian soal itu dikumpul atau dinilai, kemudian dibahas secara bersama-sama untuk 
membantu siswa dalam melatih memahami materi pelajaran yang akan diberikan.

5) Sumber bacaan adalah buku atau bahan ajar apa saja yang akan digunakan atau menjadi sumber dari materi pelajaran yang diberikan.

\section{f. Penyusunan Handout}

Handout berguna untuk membantu siswa dalam hal sebagai berikut:

a. Memperoleh informasi tambahan yang belum tentu mudah diperoleh secara cepat dari tempat lain.

b. Memberikan rincian prosedur atau teknik pelaksanaan yang terlalu kompleks bila menggunakan media audiovisual.

c. Materi yang terlalu panjang/kompleks yang telah diringkas dalam bentuk catatan yang mudah dipahami.

Keuntungan penggunaan media handout adalah sebagai berikut:

1) Dapat menghemat waktu

2) Dapat menggantikan catatan siswa

3) Memelihara kekonsistenan penyampaian materi dikelas oleh guru

4) Siswa dapat mengikuti struktur pelajaran dengan baik

5) Siswa akan mengetahui pokok yang diberikan oleh guru

Keuntungan yang diperoleh dengan menggunakan media handout dalam kegiatan belajar mengajar diantaranya adalah dapat merangsang rasa ingin tahu dalam mengikuti pelajaran, meningkatkan kreativitas siswa dalam kegiatan belajar mengajar serta memelihara kekonsistenan penyampaian materi pelajaran dikelas oleh guru sesuai dengan perancangan pengajaran. Selain itu keuntungan menggunakan media handout dalam proses mengajar antara lain:

1) Untuk memperkenalkan informasi atau teknologi baru.

2) Untuk dapat memeriksa hasil pembelajaran siswa dan mendorong keberanian siswa berprestasi.

3) Untuk dapat membantu pengetahuan ingatan dan penyempurnaan. 


\section{g. Contoh Handout}
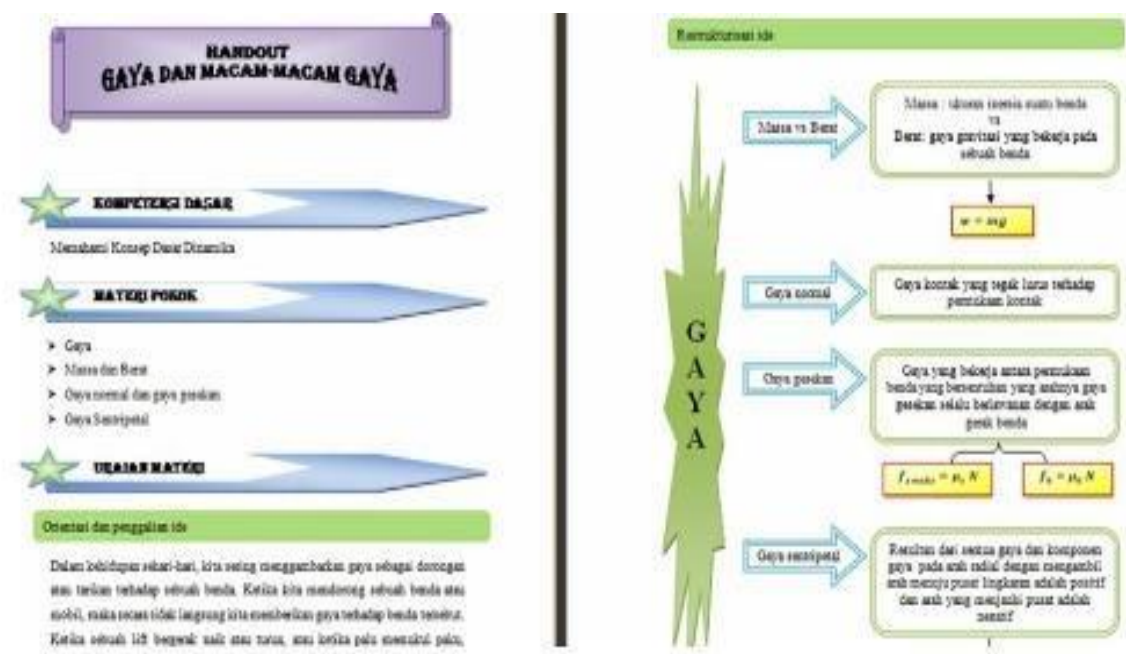

Gambar 1. Handout gaya dan macam-macam gaya

\section{Modul}

\section{a. Pengertian Modul}

Modul merupakan paket belajar mandiri yang meliputi serangkaian pengalaman belajar yang direncanakan dan dirancang secara sistematis untuk membantu siswa mencapai tujuan belajar (Setiyadi, 2017:104). Modul harus disusun secara sistematis artinya sesuai dengan tujuan yang akan dicapai, karakteristik dan kebutuhan sehingga siswa dapat belajar secara mandiri (Asrizal, 2013: 31). Modul adalah sebuah buku yang ditulis dengan tujuan agar peserta didik dapat belajar secara mandiri tanpa atau dengan bimbingan guru, sehingga bagian-bagian modul menurut Depdiknas (2010:35), yaitu:

1) Judul/identitas

2) Petunjuk Belajar

3) $\mathrm{SK} / \mathrm{KD}$

4) Materi Pembelajaran

5) Informasi pendukung

6) Paparan isi materi

7) Latihan

8) Tugas/Langkah Kerja

9) Penilaian 
Sebuah modul akan bermakna kalau peserta didik dapat dengan mudah menggunakannya. Pembelajaran dengan modul memungkinkan seorang peserta didik yang memiliki kecepatan tinggi dalam belajar akan lebih cepat menyelesaikan satu atau lebih KD dibandingkan dengan siswa atau peserta didik lainnya.

Pembelajaran dengan modul memiliki ciri-ciri (Vembriarto, 1985: 27) sebagai berikut:

\section{1) Bersifat self-instructional}

Pengajaran modul menggunakan paket pelajaran yang memuat satu konsep atau unitdari bahan pelajaran. Sementara, pendekatan yang digunakan dalam pengajaranmodul menggunakan pengalaman belajar siswa melalui berbagai macampenginderaan, melalui pengalaman mana siswa terlibat secara aktif belajar.

2) Pengakuan atas perbedaan-perbedaan individual

Pembelajaran melalui modul sangat sesuai untuk menanggapi perbedaan individualsiswa, karena modul pada dasarnya disusun untuk diselesaikan oleh siswa secaraperorangan. Oleh karena itu pembelajaran melalui modul, siswa diberi kesempatanbelajar sesuai irama dan kecepatan masing-masing.

3) Memuat rumusan tujuan pembelajaran/kompetensi dasar secara eksplisit

Tiap-tiap modul memuat rumusan tujuan pengajaran/kompetensi dasar secara spesifik dan eksplisit. Hal ini sangat berguna bagi berbagai pihak seperti bagi penyusun modul, guru dan bagi siswa. Bagi penyusun modul, tujuan yang spesifik berguna untuk menentukan media dan kegiatan belajar yang harus direncanakan untukmencapai tujuan tersebut. Bagi guru tujuan itu berguna untuk memahami isipelajaran. Bagi siswa berguna untuk menyadarkan mereka tentang apa yang diharapkan.

4) Adanya asosiasi, struktur dan urutan pengetahuan

Proses asosiasi terjadi karena dengan modul siswa dapat membaca teks dan melihat diagram-diagram dan buku modulnya. Sedangkan struktur dan urutan maksudnya materi pada buku modul itu dapat disusun mengikuti struktur pengetahuan secara hirarkis. 
5) Penggunaan berbagai macam media (multi media)

Modul adalah alat ukur yang lengkap. Modul adalah satu kesatuan program yang dapat mengukur tujuan. Modul dapat dipandang sebagai paket program yang disusun dalam bentuk satuan tertentu guna keperluan belajar.

Menurut panduan pengembangan bahan ajar Depdiknas (2008:19), fungsi modul dijabarkan sebagai berikut :

1) Pedoman bagi guru yang akan mengarahkan semua aktivitasnya dalam proses pembelajaran, sekaligus merupakan substansi yang seharusnya diajarkan kepada siswa;

2) pedoman bagi siswa yang akan mengarahkan semua aktivitasnya dalam proses pembelajaran sekaligus substansi kompetensi yang seharusnya dikuasai;

3) alat evaluasi pencapaian dan penguasaaan hasil pembelajaran yang telah dilakukan.

Keuntungan yang diperoleh dari pembelajaran dengan penerapan modul adalah sebagai berikut:

1) Meningkatkan motivasi siswa, karena setiap kali mengerjakan tugas pelajaran yang dibatasi dengan jelas dan sesuai dengan kemampuan.

2) Setelah dilakukan evaluasi, guru dan siswa mengetahui benar, pada modul yang mana siswa telah berhasil dan pada bagian modul yang mana mereka belum berhasil.

3) Siswa mencapai hasil sesuai dengan kemampuannya.

4) Bahan pelajaran terbagi lebih merata dalam satu semester.

5) Pendidikan lebih berdaya guna, karena bahan pelajaran disusun menurut jenjang akademik.

\section{b. Jenis-Jenis Modul}

Jenis modul dapat dibagi menjadi dua bentuk sebagai berikut:

1) Modul sederhana, yaitu bahan pembelajaran tertulis yang hanya terdiri atas 3-5 halaman, bahan pembelajaran ini dibuat untuk kepentingan pembelajaran selama 1-2 jam pelajaran. 
2) Modul kompleks, yaitu bahan pembelajaran yang terdiri 40-60 halaman, untuk 20-30 jam pelajaran. Modul kompleks ini dapat dilengkapi bahan audio, video/film, kegiatan percobaan, praktikum, dsb.

\section{c. Karakteristik Modul}

Karakteristik modul dapat diketahui dari formatnya yang disusun atas dasar:

1) Prinsip-prinsip desain pembelajaran yang berorientasi kepada tujuan (objective model)

2) Prinsip belajar mandiri

3) Prinsip belajar maju berkelanjutan (continuous progress)

4) Penataan materi secara modular yang utuh dan lengkap (self contained)

5) Prinsip rujuk silang (cross referencing) antar modul dalam mata pelajaran

6) Penilaian belajar mandiri terhadap kemajuan belajar (self-evaluation).

Karakteristik modul, yaitu:

1) Self Instructional merupakan karakteristik yang terpenting dalam sebuah modul. Modul dapat dikatakan memenuhi karakteristik tersebut apabila modul mampu membelajarkan siswa secara mandiri tanpa memerlukan pihak lain secara utuh. Untuk memenuhi karakter self instructional, maka dalam modul harus:

a) berisi tujuan yang dirumuskan dengan jelas.

b) berisi materi pembelajaran yang dikemas ke dalam unit-unit kecil/ spesifik sehingga memudahkan belajar secara tuntas.

c) menyediakan contoh dan ilustrasi yang mendukung kejelasan pemaparan materi pembelajaran.

d) menampilkan soal-soal latihan, tugas dan sejenisnya yang memungkinkan pengguna memberikan respon dan mengukur tingkat penguasaannya.

e) kontekstual yaitu materi-materi yang disajikan terkait dengan suasana atau konteks tugas dan lingkungan penggunanya.

f) menggunakan bahasa yang sederhana dan komunikatif.

g) terdapat rangkuman materi pembelajaran.

h) terdapat instrumen penilaian/assessment, yang memungkinkan penggunaan diklat melakukan ,self assessment. 
i) terdapat instrumen yang dapat digunakan penggunanya mengukur atau mengevaluasi tingkat penguasaan materi.

j) terdapat umpan balik atas penilaian, sehingga penggunanya menge- tahui tingkat penguasaan materi.

k) tersedia informasi tentang rujukan/pengayaan/referensi yang mendukung materi pembelajaran dimaksud ( Tim Penyusun, 2008 ).

2) Self contained apabila dalam modul tersebut berisi satu unit atau sub unit pembelajaran yang keseluruhan materinya termuat dalam modul tersebut secara utuh. Tujuannya adalah agar siswa dapat mempelajari materi secara tuntas. Jika dilakukan pembagian atau pemisahan materi dari satu unit kompetensi harus dilakukan dengan hati-hati dan memperhatikan keluasan kompetensi yang harus dikuasai.

3) Stand alone adalah modul yang dikembangkan tidak bergantung pada bahan ajar atau media lainnya. Siswa tidak perlu menggunakan bahan ajar lain ketika menggunakan modul tersebut. Jika siswa masih bergantung dengan bahan ajar, atau media lainnya, maka modul tersebut tidak termasuk sebagai bahan ajar yang berdiri sendiri.

4) Adaptif. Modul hendaknya memiliki daya adaptif dengan perkembangan ilmu dan teknologi. Pemberian konten yang mendukung pembelajaran dalam sebuah modul seperti audio, visual atau audio visual merupakan contoh dari karakteristik adaptif modul. Melalui karakteristik ini, mendukung modul untuk 15 bisa berdiri sendiri karena konten tersebut disajikan di dalam sebuah modul, tidak dengan media lainnya.

5) User Friendly. Modul dikatakan memiliki karakteristik seperti ini apabila modul bersahabat dengan pemakainya. Setiap instruksi dan paparan informasi yang tampil bersifat membantu dan bersahabat dengan pemakainya, termasuk kemudahan pemakai dalam merespon, mengakses sesuai dengan keinginan. Penggunaan bahasa yang sederhana, mudah dimengerti serta menggunakan istilah yang umum digunakan merupakan salah satu bentuk user friendly 


\section{d. Prinsip Penyusunan Modul}

Penyusunan modul memperhatikan beberapa prinsip-prinsip yang memenuhi tujuan penyusunannya, diantaranya:

1) Disusun dari materi yang mudah untuk memahami yang kebih sulit, dan dari yang konkret untuk memahami yang semikonkret dan abstrak

2) Menekankan pengulangan untuk memperkuat pemahaman

3) Umpan balik yang positif akan memberikan penguatan terhadap siswa

4) Memotivasi adalah salah satu upaya yang dapat menentukan keberhasilan belajar

5) Latihan dan tugas untuk menguji diri sendiri.

\section{e. Alur Penyusunan Modul}

Penyusunan sebuah modul pembelajaran diawali dengan urutan kegiatan sebagai berikut:

1) Menetapkan judul modul yang akan disusun

2) Menyiapkan buku-buku sumber dan buku referensi lainnya

3) Melakukan identifikasi terhadap kompetensi dasar, melakukan kajian terhadap materi pembelajarannya, serta merancang bentuk kegiatan pembelajaran yang sesuai.

4) Mengidentifikasi indikator pencapaian kompetensi dan merancang bentuk dan jenis penilaian yang akan disajikan

5) Merancang format penulisan modul

6) Penyusunan draf modul.

\section{f. Unsur-unsur Modul}

Pembuatan modul yang baik dan benar salah satu yang terpenting dan harus dimengerti adalah struktur bahan ajar, seperti modul paling tidak berisi tentang tujuh komponen sebagai berikut: judul, petunjuk belajar (petunjuk siswa dan pendidik), kompetensi yang akan dicapai, informasi pendukung, latihan, petunjuk kerja atau dapat pula berupa lembar kerja dan evaluasi.

Menurut Vembrianto (1985:37-38) modul yang dibuat dan dirumuskan dapat memuat beberapa unsur di dalamnya seperti berikut: 
1) Rumusan Tujuan Pengajaran

2) Petunjuk untuk Guru

3) Lembaran Kegiatan Siswa

4) Lembaran Kerja Siswa

5) Kunci Lembaran Kerja

6) Lembar Evaluasi

7) Kunci Lembaran Evaluasi

Dari penjelasan unsur-unsur pembuatan modul tersebut, secara teknis modul tersusun dalam empat unsur yaitu:

1) Judul Modul

Judul yang berisi tentang nama modul dari suatu materi atau mata kuliah.

2) Petunjuk Umum

Unsur ini memuat penjelasan tentang langkah-langkah yang akan ditempuh dalam pembelajaran, sebagai berikut:

a) Kompetensi dasar

b) Pokok bahasan

c) Indikator pencapaian

d) Referensi

e) Strategi pembelajaran

f) Menjelaskan pendekatan, metode, dan langkah yang akan digunakan dalam proses pembelajaran

g) Lembar kegiatan pembelajaran

h) Petunjuk bagi siswa atau mahasiswa untuk memahami langkah-langkah dan materi perkuliahan

i) Evaluasi

3) Materi Modul

Berisi penjelasan secara terperinci tentang materi yang dikuliahkan atau dibelajarkan pada setiap pertemuan.

4) Evaluasi Semester

Bertujuan untuk mengukur kompetensi mahasiswa sesuai materi perkuliahan atau pembelajaran yang diberikan. 


\section{g. Jenis-jenis Modul}

1) Menurut Penggunaanya dilihat dari penggunaanya, modul terbagi menjadi dua macam, yaitu:

a) Modul untuk peserta didik

Modul untuk peserta didik berisi kegiatan belajar yang dilakukan oleh peserta didik.

b) Modul untuk Pendidik

Modul untuk pendidik berisi petunjuk pendidik, tes akhir modul, dan kunci jawaban akhir modul.

2) Menurut Tujuan Penyusunannya, Vembrianto membedakan modul menjadi dua macam yaitu:

a) Modul Inti

Modul inti adalah modul yang disusun dari kurikulum dasar, yang merupakan tuntutan dari pendidikan dasar umum yang diperlukan oleh seluruh warga Negara Indonesia. Modul pengajaran ini merupakan hasil penyusunan dari unit-unit program yang disusun menurut tingkat (kelas) dan bidang studi (mata pelajaran). Unit-unit program itu sendiri diperoleh dari hasil penjabaran kurikulum dasar. Adapun kurikulum dasar didudun untuk memberikan pendidikan dasar umum bagi semua sekolah dasar dan menengah.

b) Modul Pengayaan

Modul pengayaan adalah modul hasil dari penyusunan unit-unit program pengayaan yang berasal dari program pengayaan yang bersifat memperluas (dimensi horizontal) dan/atau bersifat memperdalam (dimensi vertikal) program pendidikan dasar yang bersifat umum tersebut.

Modul ini disusun sebagai bagian dari usaha untuk mengakomodasi peserta didik yang telah menyelesaikan dengan baik program pendidikan dasarnya melalui teman- temannya. Adanya modul pengayaan ini lembaga pendidikan akan lebih mampu mengakomodasikan siswa yang berkemampuan cepat. 


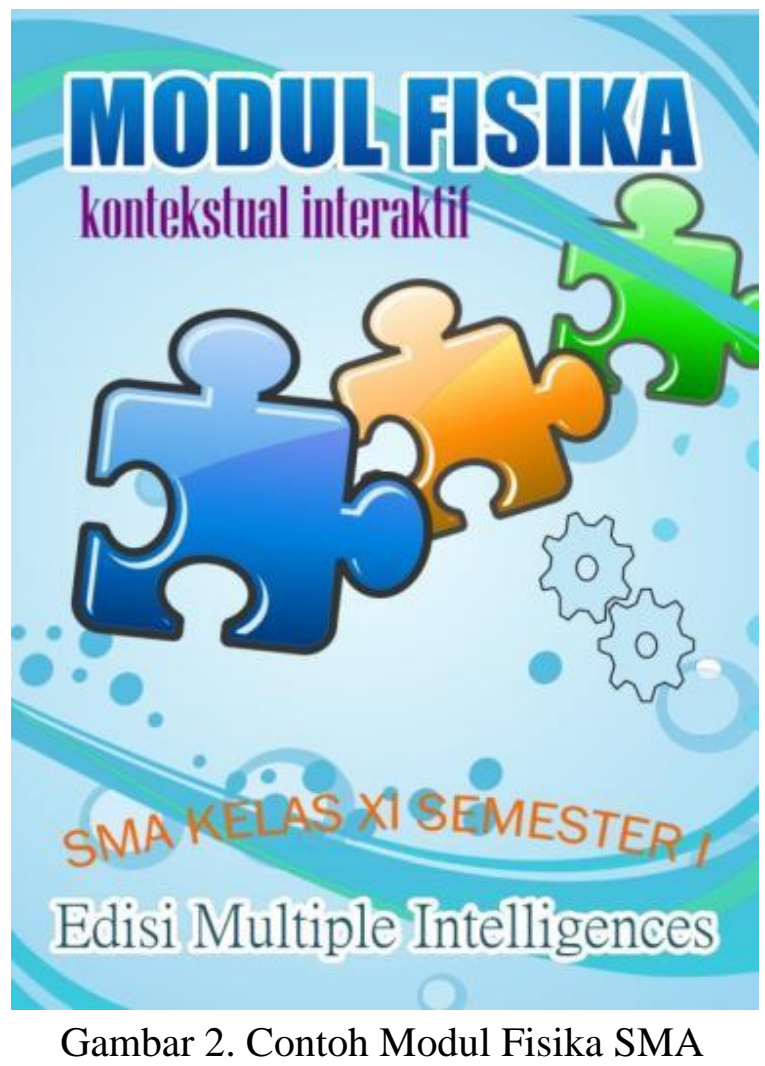

\section{Buku}

Buku adalah salah satu sumber bacaan, berfungsi sebagai sumber bahan ajar dalam bentuk materi cetak (printed material). Secara umum buku dibedakan menjadi 4 jenis:

a. Buku sumber yaitu buku yang biasa dijadikan rujukan, referensi, dan sumber untuk kajian ilmu tertentu, biasanya berisi suatu kajian ilmu yang lengkap,

b. Buku bacaan, adalah buku yang hanya berfungsi untuk bahan bacaan saja, misalnya novel, cerita, legenda, dll,

c. Buku pegangan, yaitu buku yang bisa dijadikan pegangan guru atau pengajar dalam melakukan proses pengajaran

d. Buku bahan ajar, yaitu buku ynag disusun, untuk proses pembelajaran, dan beisi bahan-bahan atau materi pelajaran yang akan diajarkan,

Buku adalah bahan tertulis yang menyajikan ilmu pengetahuan buah pikiran dari pengarangnya. Oleh pengarangnya isi buku didapat dari berbagai cara misalnya: hasil penelitian, hasil pengamatan, aktualisasi pengalaman, otobiografi, 
atau hasil imajinasi seseorang yang disebut sebagai fiksi. Buku adalah sejumlah lembaran kertas baik cetakan maupun kosong yang dijilid dan diberi kulit. Buku sebagai bahan ajar merupakan buku yang berisi suatu ilmu pengetahuan hasil analisis terhadap kurikulum dalam bentuk tertulis.

Buku yang baik adalah buku yang ditulis dengan menggunakan bahasa yang baik dan mudah dimengerti, disajikan secara menarik dilengkapi dengan gambar dan keterangan-keterangannya, isi buku juga menggambarkan sesuatu yang sesuai dengan ide penulisannya. Buku pelajaran berisi tentang ilmu pengetahuan yang dapat digunakan oleh peserta didik untuk belajar, buku fiksi akan berisi tentang fikiran-fikiran fiksi si penulis, dan seterusnya. Buku meliputi sebagai berikut:

\section{a. Diktat}

\section{1) Pengertian Diktat}

Pengertian diktat menurut kamus besar Indonesia adalah pegangan yang dibuat guru berupa kutipan bentuk tulisan atau ketikan. Secara umum, diktat adalah catatan tertulis suatu mata pelajaran atau bidang studi yang dipersiapkan guru untuk mempermudah/memperkaya materi mata pelajaran / bidang studi yang disampaikannya dalam proses pembelajaran. Biasanya diktat hanya diedarkan dalam lingkup terbatas.

\section{2) Jenis-jenis Diktat}

Diktat sama seperti buku terdiri dari tiga bagian yang mencakup :

a) Bagian awal yang berisi :

(1) Halaman cover, bersisi tentang judul, pengarang, gambar sampul, dan lingkup penggunaan diktat (biasanya digunakan untuk lingkungan sendiri), nama departemen, tahun terbit.

(2) Halaman judul, berisi judul, pengarang/penulis, gambar sampul, lingkup penggunaan, tahun terbit, nama depertemen

(3) Daftar isi, yang membuat, judul bab, sub bab, dan nomor halaman

(4) Daftar lain seperti : daftar gambar, daftar table, daftar lampiran.

b) Bagian isi

Bagian ini berisi pokok pokok bahasan yang menjadi inti naskah diktat dan memuat uraian penjelasan, proses operasional atau langkah kerja dari setiap 
bab maupun sub bab. Dengan demikian paragraf merupakan unit terkecil suatu pokok bahasan. Paragraf tersebut harus saling mendukung dan merupakan suatu kesatuan yang koheren. Apabila diperlukan penjelasan dan uraian dilengkapi dengan table, bagan, gambar dan ilustrasi lain.

c) Bagian Akhir

(1) Lampiran, bila lampiran lebih dari satu lembar harus diberi nomor urut arab

(2) Glosarium (jika ada), kata/istilah yang berhubungan dengan uraian diktat sehingga memudahkan pemahaman pembanca

(3) Kepustakaan

\section{3) Karakteristik Diktat}

Ada beberapa prinsip yang perlu diperhatikan dalam penyusunan diktat antara lain prinsip relevansi, konsistensi dan kecukupan.

a) Prinsip relevansi artinya keterkaitan, materi yang ditulis hendaknya relevan dengan pencapaian standar kompetensi yang ingin dicapai.

b) Prinsip konsistensi artinya keajegan, jika kompetensi dasar yang harus dikuasai empat macam maka bahasan yang ada pada diktat juga harus meliputi empat macam.

c) Prinsip kecukupan artinya materi yang diajarkan hendaknya mencukupi dalam membantu siswa mengusai kompetensi yang akan diajarkan, materi juga disesuaikan dengan alokasi waktu yang tersedia.

Adapun secara garis besar, cara membuat diktat adalah sebagai berikut:

a) Memetakan Standar Kompetensi (SK), Kompetensi Dasar (KD), dan Indikator yang diharapkan dicapai oleh siswa.

b) Mencari materi yang relevan dengan $\mathrm{SK}, \mathrm{KD}$, dan Indikator pembelajaran.

c) Meringkas materi/pokok-pokok materi.

d) Membuat rincian penjelasan pada materi yang diajarkan.

e) Membuat evaluasi untuk mengukur ketercapaian kompetensi.

f) Mencantumkan sumber-sumber/referensi yang digunakan untuk membuat diktat.

g) Mengajukan review dan pengesahan dari pejabat yang berwenang. 


\section{4) Contoh Diktat}

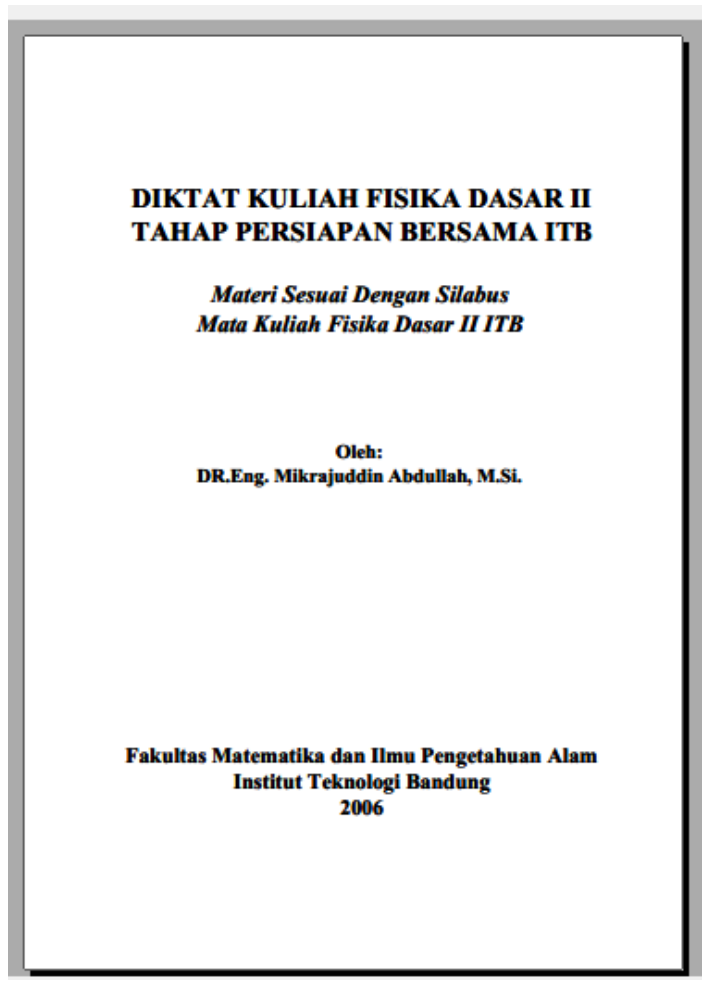

Gambar 3. Contoh Diktat Fisika Dasar

\section{b. Buku Ajar}

\section{1) Pengertian Buku Ajar}

Buku ajar adalah yaitu buku ynag disusun, untuk proses pembelajaran, dan beisi bahan-bahan atau materi pelajaran yang akan diajarkan ,yang telahdisusun secara sistematis. Struktur dan urutannya sistematis, menjelaskan tujuan instruksional yang akan dicapai, memotivasi siswa untuk belajar, mengantisipasi kesukaran siswa dengan meyediakan bimbingan belajar, memberi latihan yang cukup, menyediakan rangkuman, berorientasi kepada siswa secara individual. Bahan ajar bersifat mandiri, artinya dapat dipelajari sendiri oleh siswa karena sistematis dan lengkap.

Buku ajar merupakan suatu kesatuan unit pembelajaran yang berisi informasi, pembahasan serta evaluasi. Buku ajar yang tersusun secara sistematis akan mempermudah peserta didik dalam materi sehingga mendukung ketercapaian tujuan pembelajaran. Buku ajar ini tidak hanya memuat judul, KD, materi pokok, informasi pendukung dan latihan buku ajar dapat dijadikan sebagai 
pendukung aktivitas pembelajaran yang bermuatan kecerdasan komprehensif atau menyeluruh (Asrizal, 2017: 74).

Menurut Greene dan Petty, beberapa kegunaan buku ajar adalah sebagai berikut.

a) Mencerminkan suatu sudut pandang yang tangguh dan modern mengenai pengajaran serta mendemontrasikan aplikasi dalam bahan pengajaran yang disajikan.

b) Menyajikan suatu sumber pokok masalah atau subject matter yang kaya, mudah dibaca dan bervariasi, yang sesuai dengan minat dan kebutuhan para siswa, sebagai dasar bagi program-program kegiatan yang disarankan di mana keterampilan-keterampilan ekspresional diperoleh pada kondisi yang menyerupai kehidupan yang sebenarnya.

c) Menyediakan suatu sumber yang tersusun rapi dan bertahap mengenai keterampilan-keterampilan ekspresional.

d) Menyajikan (bersama-sama dengan buku manual yang mendampinginya) metode-metode dan sarana-sarana pengajaran untuk memotivasi siswa.

e) Menyajikan fiksasi awal yang perlu sekaligus juga sebagai penunjang bagi latihan dan tugas praktis.

f) Menyajikan bahan atau sarana evaluasi dan remedial yang serasi dan tepat guna.

\section{2) Karakteristik Buku Ajar}

Menurut Tarigan (1986:89) menjelaskan kriteria buku ajar yang dianggap baik yang tediri atas delapan kriteria sebagai berikut.

a) Organisasi dan Sistematika

Pengertian organisasi mengandung arti susunan (atau cara bersusun) sesuatu yang terdiri atas komponen atau topik dengan tujuan tertentu, sedangkan sistematika adalah kaidah atau aturan dalam buku ajar yang harus diikuti.

b) Kesesuaian Isi dengan Kurikulum

Materi atau bahan pelajaran merupakan unsur inti yang ada di dalam kegiatan belajar mengajar, karena memang bahan pelajaran itulah yang diupayakan untuk dikuasai oleh anak didik. Karena itu pula, guru 
khususnya, atau pengembangan Kurikulum umumnya, harus memikirkan sejauh mana bahan-bahan atau topik yang tertera dalam silabus berkaitan dengan kebutuhan peserta didik di masa depan.

c) Kesesuaian Pengembangan Materi dengan Tema/Topik

Materi-materi pembelajaran dalam buku ajar dikembangkan oleh penulisnya denganmemperhatikan topik-topik pembelajaran yang terdapat dalam kurikulum.

d) Perkembangan Kognitif

Perkembangan kognitif siswa juga perlu dipertimbangan dalam penulisan dan pemilihan buku ajar. Jadi, untuk dapat memanfaatkan materi-materi pembelajaran yang menunjang kemampuan siswa, sebaiknya memilih materi yang memiliki tingkat kesulitan sedikit di atas rata-rata pada saat proses pembelajaran.

e) Keserasian Ilustri dengan Wacana/Teks Bacaan

Buku ajar harus selalu disertai dengan ilustrai atau gambar agar buku ajar menarik bagi siswa.

\section{3) Contoh Buku Ajar}

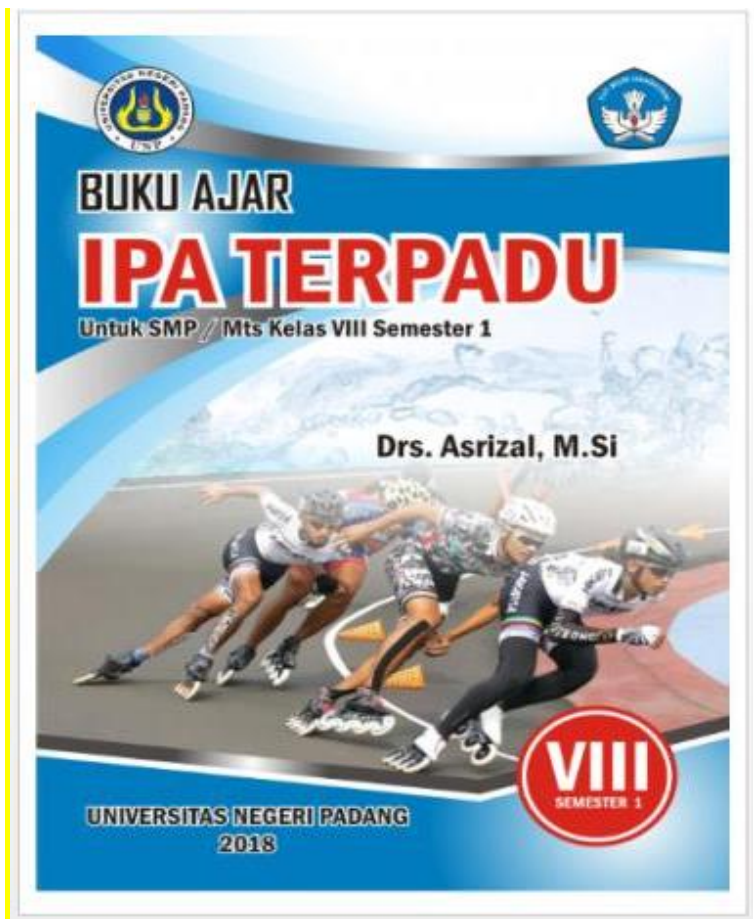

KOMPETENSI DASAR DAN INDIKATOR

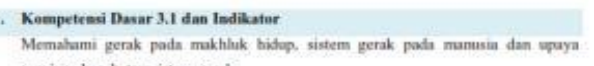
Indikater

Indikator
Mengidentifikasi gerak pudu makthik hidup.

Meajelaskan gerak poch tumbohun

Menjelaskan garak pade hewain.

Meajelaskan siserm gerak pada manuei.

Menjelaskan ganepuan pada sistem gerak masaxis

Menjeladian upays menjaps kesclatan tumbehen

2. Kompetensi Dasar 4.I das Inatikater

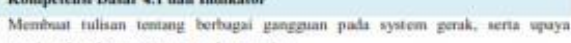
menjaga kenehatan myterm gorak mannuia

Insikatar

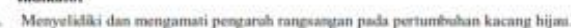

Menyelidiai keceputan reapon patri malu verhadap pemberian rangangan yang

bertiont

Meseran a

Menter a

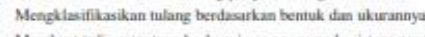

Mentuat tulban tentang bertugai gangeran pada sistem gerak manusia serta upaya

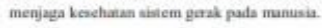

3. Kumpetemai Dasar 3.2 dan Indilater

Menganalisis gerak hirus pengaruh paya terhadop genak berdasarkan tokum

Newton dan penerapunnya pada gerak benda dan gerak maih hlak hidup.

Indikator

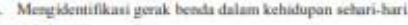

b. Mesiclaikan serak limu.

Gambar 4. Contoh Buku Ajar IPA Terpadu kelas VIII SMP 


\section{c. Buku Teks}

\section{1) Pengertian Buku Teks}

Buku teks atau buku pelajaran adalah buku yang berisi uraian bahan tentang mata pelajaran atau bidang tertentu, yang disusun secara sistematis dan telah diseleksi berdasarkan tujuan tertentu, orientasi pembelajaran dan perkembangan siswa untuk diasimilasikan. Buku ini dapat dipakai sebagai sarana belajar dalam kegiatan pembelajaran di sekolah (Agustina, 2011: 10). Buku teks juga dapat didefinisikan sebagai buku pelajaran dalam bidang studi tertentu, yang merupakan buku standar yang disusun oleh para pakar dalam bidang itu buat maksud dan tujuan-tujuan instruksional yang dilengkapi dengan sarana-sarana pengajaran yang serasi dan mudah dipahami oleh para pemakainya di sekolah-sekolah dan perguruan tinggi sehingga dapat menunjang suatu program pengajaran (Tarigan, 1986: 13). Berdasarkan pengertian-pengertian di atas dapat disumpulkan bahwa buku teks adalah buku pelajaran yang disusun sedemikian rupa untuk menunjang proses belajar mengajar yang sesuai dengan Kurikulum yng berlaku .

Menurut Prastowo (2013) penggunaan buku teks yang mudah untuk dipelajari memiliki peranan penting bagi siswa dalam memanfaatkan buku teks. Bagi siswa nuku teks dapat dijadikan sebagai sumber belajar siswa dalam memperlajari kembali materi yang telah diperoleh ketika disekolah. Keberadaan buku teks dapat digunakan siswa sebagai sumber dalam mempelajari kembali materi yang telah diajarkan dan mempelajari materi selanjutnya.

\section{2) Karakteristik Buku Teks}

Karakteristik buku teks sebagai berikut:

a) Diterbitkan dan memiliki ISBN (internasional standar book number).

b) Memiliki misi utama.

(1)Optimalisasi pengembangan pengetahuan deklaratif dan prosedural.

(2)Menjadi target utama dari buku ajar yang digunakan.

c) Mengacu pada program DEPDIKNAS.

(1)Mengikuti kurikulum pendidikan nasional yang sedang berlangsung.

(2)Berorientasi pada ketrampilan proses dengan menggunakan pendekatan kontekstual, teknologi, dan masyarakat, serta demokrasi. 
(3)Memberi gambaran secara jelas tentang keterpaduan atau keterkaitan dengan disiplin ilmu lainnya.

d) Memiliki berbagai macam keuntungan.

(1)Buku teks pelajaran membantu pendidik dalam pengajaran.

(2)Buku teks pelajaran juga meupakan pegangan dalam metode pembelajaran.

(3)Buku teks pelajaran memberikan kesempatan bagi peserta didik untuk mengulangi pelajaran atau mempelajari pelajaran baru.

(4)Buku pelajaran dapat digunakan untuk tahun-tahun berikutnya dan jika direvisi maka dapat bertahan dalam jangka waktu yang lama.

(5)Buku teks pelajaran yang univorm memberikan kesamaan mengani bahan ajar dan standar pengajaran.

(6)Buku teks pelajaran memberikan kontinuitas pelajaran di kelas yang berurutan sekalipun pendidik berganti.

(7)Buku teks pelajaran memberikan pengetahuan dan metode mengajar yang lebih mantap jika guru menggunakan dari tahun ketahun.

\section{(3) Contoh Buku Teks}

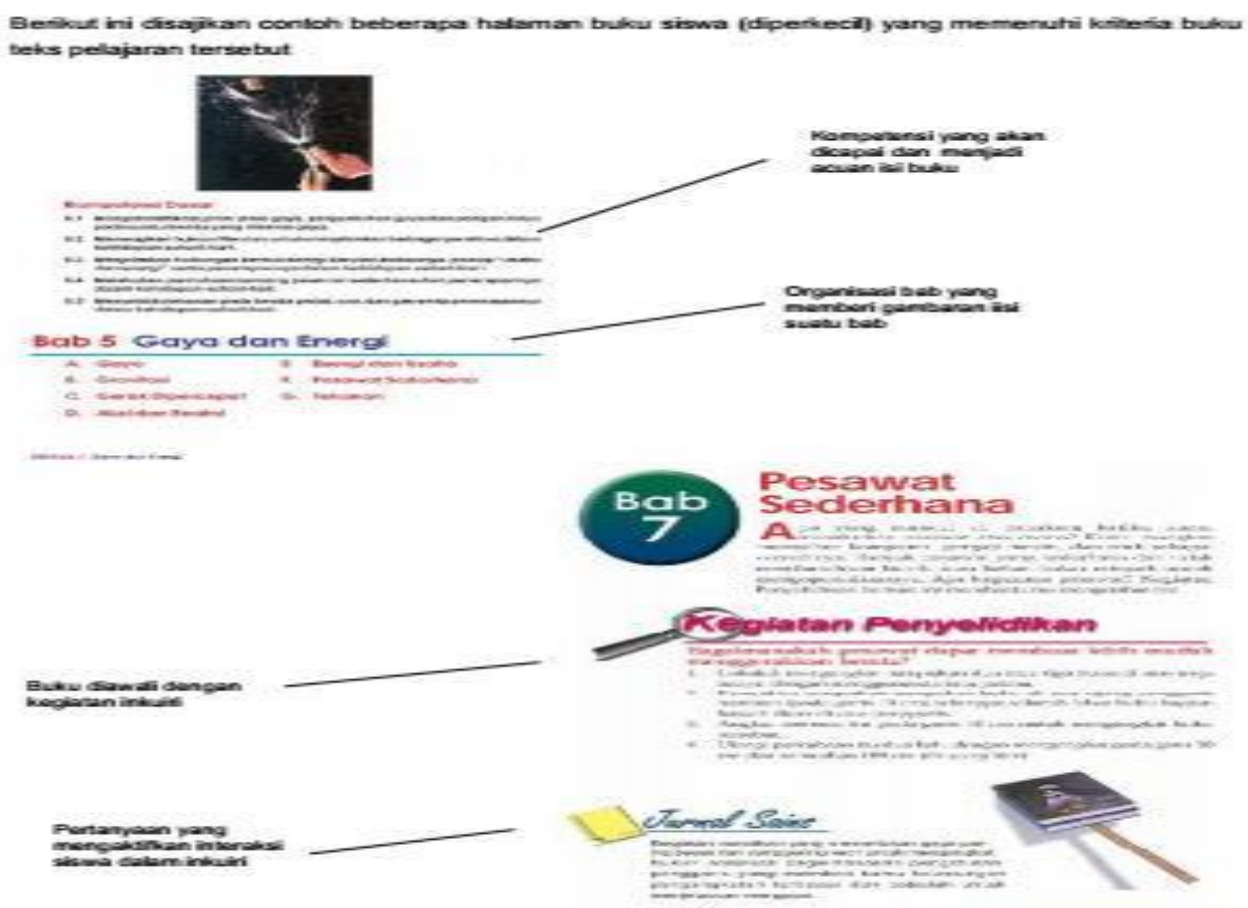

Gambar 5. Contoh Buku Teks Fisika 


\section{Lembar Kerja Siswa (LKS)}

\section{a. Pengertian LKS}

Lembar Kerja Siswa (LKS) merupakan salah satu bentuk bahan ajar cetak. LKS adalah lembaran-lembaran berisi tugas berupa pertanyaan-pertanyaan dan langkah-langkah kegiatan penyelidikan atau pemecahan masalah yang harus dijawab dan dikerjakan oleh siswa yang bertujuan untuk memberikan kemudahan siswa dalam memahami materi yang diajarkan dalam proses pembelajaran. Hal ini sejalan dengan pendapat Majid (2012:176) menyatakan bahwa LKS adalah lembaran-lembaran berisi tugas yang harus dikerjakan oleh siswa.

Lembar kegiatan siswa (student worksheet) adalah lembaran-lembaran berisi tugas yang harus dikerjakan oleh peserta didik. Lembar kegiatan biasanya berupa petunjuk, langkah-langkah untuk menyelesaikan suatu tugas. Suatu tugas yang diperintahkan dalam lembar kegiatan harus jelas KD yang akan dicapainya. Lembar kegiatan dapat digunakan untuk mata pembelajaran apa saja.Tugas-tugas sebuah lembar kegiatan tidak akan dapat dikerjakan oleh peserta didik secara baik apabila tidak dilengkapi dengan buku lain atau referensi lain yang terkait dengan materi tugasnya.

Menurut Depdiknas (2008: 23-24), LKS adalah lembaran-lembaran berisi tugas yang harus dikerjakan oleh peserta didik. Lembar kerja siswa akan memuat paling tidak; judul, KD yang akan dicapai, waktu penyelesaian, peralatan/bahan yang diperlukan untuk menyelesaikan tugas, informasi singkat, langkah kerja, tugas yang harus dilakukan, dan laporan yang harus dikerjakan

Keuntungan adanya lembar kegiatan adalah bagi guru, memudahkan guru dalam melaksanakan pembelajaran, bagi siswa akan belajar secara mandiri dan belajar memahami dan menjalankan suatu tugas tertulis. Berdasarkan penelitian yang dilakukan oleh Febrianti (2015:2) menyatakan bahwa LKS dapat meningkatkan kompetensi peserta didik dalam memecahkan masalah, bekerja sama dan berkomunikasi. Dalam menyiapkannya guru harus cermat dan memiliki pengetahuan dan keterampilan yang memadai, karena sebuah lembar kerja harus memenuhi paling tidak kriteria yang berkaitan dengan tercapai/ tidaknya sebuah KD dikuasai oleh peserta didik 


\section{b. Tujuan LKS dan Kegunaan LKS}

Adapun tujuan LKS:

1) Mengaktifkan siswa dalam proses kegiatan pembelajaran

2) Membantu siswa mengembangkan konsep

3) Melatih siswa untuk menemukan dan mengembangkan keterampilan

4) Sebagai pedoman guru dan siswa dalam melaksanakan proses kegiatan pembelajaran

5) Membantu siswa memperoleh informasi tentang konsep yang dipelajari melalui proses kegiatan pembelajaran secara sistematis

6) Membantu siswa dalam memperoleh catatan materi yang dipelajari melalui kegiatan pembelajaran

Sedangkan kegunaan LKS adalah sebagai berikut:

1) Memberikan pengalaman konkret bagi siswa

2) Membantu variasi belajar

3) Membangkitkan minat siswa

4) Meningkatkan retensi belajar mengajar

5) Memanfaatkan waktu secara efektif dan efisien

\section{c. Struktur LKS}

Struktur LKS secara umum adalah sebagai berikut:

1) Judul

2) Petunjuk belajar (Petunjuk siswa)

3) Kompetensi yang akan dicapai

4) Informasi pendukung

5) Tugas-tugas dan langkah-langkah kerja

6) Penilaian

\section{d. K omponen LKS}

Lembar Kerja Siswa atau yang biasa disebut dengan LKS tersusun dengan komponen-komponen sebagai berikut:

1) Kata pengantar

2) Daftar isi 
3) Pendahuluan ( berisi analisis / daftar dari tujuan pembelajaran dan indikator ketercapaian berdasarkan hasil analisis dari GBPP)

4) Bab 1 berisi tentang ringkasan materi/penekanan materi dari pokok bahasan tersebut.

5) Lembar kerja : berisi berbagai soal ataupun penugasan yang akan dikerjakan oleh siswa

6) Bab 2 berisi tentang ringkasan materi/penekanan materi dari pokok bahasan tersebut.

7) Lembar kerja dst.

8) Daftar pustaka

\section{e. Karakteristik LKS}

LKS memiliki karakteristik yang sedikit berbeda dengan bahan ajar lainnya, yakni sebagai berikut:

a. LKS memiliki soal-soal yang harus dikerjakan siswa, dan kegiatan-kegitan seperti percobaan atau terjun ke lapangan yang harus siswa lakukan.

b. Merupakan bahan ajar cetak.

c. Materi yang disajikan merupakan rangkuman yang tidak terlalu luas pembahasannya tetapi sudah mencakup apa yang akan dikerjakan atau dilakukan oleh peserta didik.

d. Memiliki komponen-komponen seperti kata pengantar, pendahuluan, daftar isi,

\section{f. Jenis-jenis LKS}

Berdasarkan perbedaan dan tujuan pengembangan materi pada masingmasing LKS, maka LKS dapat dibedakan sebagai berukut:

1) LKS Penemuan (Membantu siswa menemukan suatu konsep)

LKS jenis ini berisikan apa saja kegiatan yang harus dilakukan siswa untuk menuntut siswa menemukan konsep sendiri. Kegiatan tersebut meliputi, melakukan, mengamati dan menganalisis. Rumuskan langkah-langkah yang harus dikalukan siswa kemudian mintalah siswa untuk mengamati fenomena hasil kegiatannya dan berilah pertanyaan analisis yang membantu siswa mengaitkan fenomena yang diamati dengan konsep yang akan dibangun siswa tersebut. 
2) LKS yang Aplikatif-Integratif

Didalam sebuah pembelajaran, setelah siswa berhasil menemukan konsep, siswa tersebut selanjutnya kita latih untuk menerapkan konsep yang telah dipelajari tersebut dalam kehidupan sehari-hari.

3) LKS Penuntun (Berfungsi sebagai penuntun belajar)

LKS penuntun berisi pertanyaan atau isian yang jawabannya ada didalam buku. Siswa dapat mengerjakan LKS tersebut jika ia membaca buku, sehingga fungsi utama LKS ini adalah membantu siswa mencari, menghafal, dan memahami materi pembelajaran yang terdapat didalam buku. LKS ini juga cocok untuk keperluan remedial.

4) LKS Penguatan (Berfungsi sebagai penguatan materi)

LKS penguatan diberikan setelah siswa selesai selesai mempelajari topic tertentu. Materi pembelajaran yang dikemas di dalam LKS penguatan lebih menekankan dan mengarahkan kepada pendalaman dan penerapan materi pembelajaran yang terdapat di dalam buku ajar.

5) LKS Praktikum (Berfungsi sebagai petunjuk praktikum)

Tanpa memisahkan petunjuk praktikum ke dalam buku tersendiri, kita dapat menggabungkan petunjuk praktikum kedalam kumpulan LKS.

\section{g. Contoh LKS}
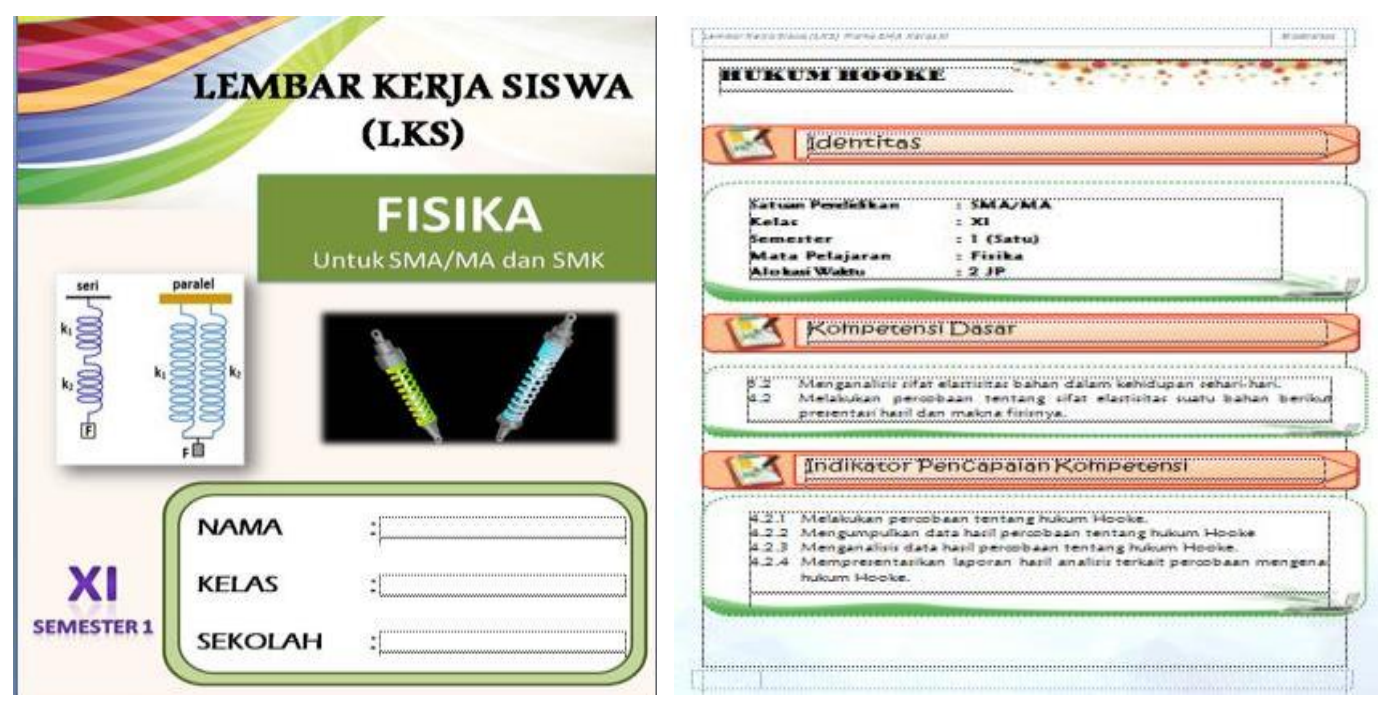

Gambar 6. Contoh LKS Fisika 


\section{Pamflet}

\section{a. Pengertian Pamflet}

Pamflet adalah selebaran kertas yang berukuran tidak tebal yang didalamnya berisi tentang suatu tulisan. Unesco mendefinisikannya sebagai keperluan publikasi yang bisa terdiri dari 5 sampai 48 halaman tanpa sampul, bila lebih dari itu disebut buku.Pamflet adalah sebuah selebaran yang memuat informasiinformasi tertentu yang dibuat oleh perusahaan atau organisasi dan ditujukan kepada masyarakat luas.

\section{b. Fungsi Pamflet}

Pamflet digunakan sebagai alat menyampaikan suatu pesan atau informasi kepada pembaca mengenai sesuatu hal,misalnya produk, sosialisasi, pengumuman, dan lain-lain

\section{c. Struktur Pembuatan Pamflet}

Struktur pembuatan pamlet, yaitu:

1) Tentukan pesan yang akan disampaikan.

Pamflet yang baik disusun berdasarkan satu pesan, tujuan, atau masalah.

2) Tambahkan penjelasan singkat tentang organisasi atau badan yang menyelenggarakan.

3) Pilih permintaan aksi.

Putuskan hal apa yang akan dipromosikan oleh pamflet.

4) Gunakan bahasa umum yang mudah dimengerti oleh semua orang.

5) Masukkan informasi kontak.

6) Teks dan gambar terpisah.

Pisahkan informasi tambahan menjadi bagian teks pendek yang bisa dibagi.

Berikut ini cara memformat informasi pamflet:

1) Logo diletakkan pada bagian depan dan belakang pamplet.

2) Kalimat utama untuk bagian depan dan isi pamflet.

3) Jenis dan format huruf untuk bagian teks.

a) Jangan menulis teks dengan ukuran kurang dari 12,karena teks akan sulit dibaca. 
b) Gunakan huruf tebal dan miring untuk menunjukkan informasi.

c) Jangan gunakan lebih dari dua jenis huruf.

4) Gunakan poin untuk mengatur daftar informasi.

5) Menggunakan warna yang menarik pembaca

b. Karakteristik pamflet

Karakteristik pamlet, yaitu:

1) Pada umumnya menggunakan bahasa yang singkat, jelas dan persuasif.

2) Ditulis dengan jelas (huruf cetak) supaya mudah terbaca.

3) Tema-tema yang digunakan pada umumnya yang aktual (up to date).

\section{c. Contoh Pamflet}
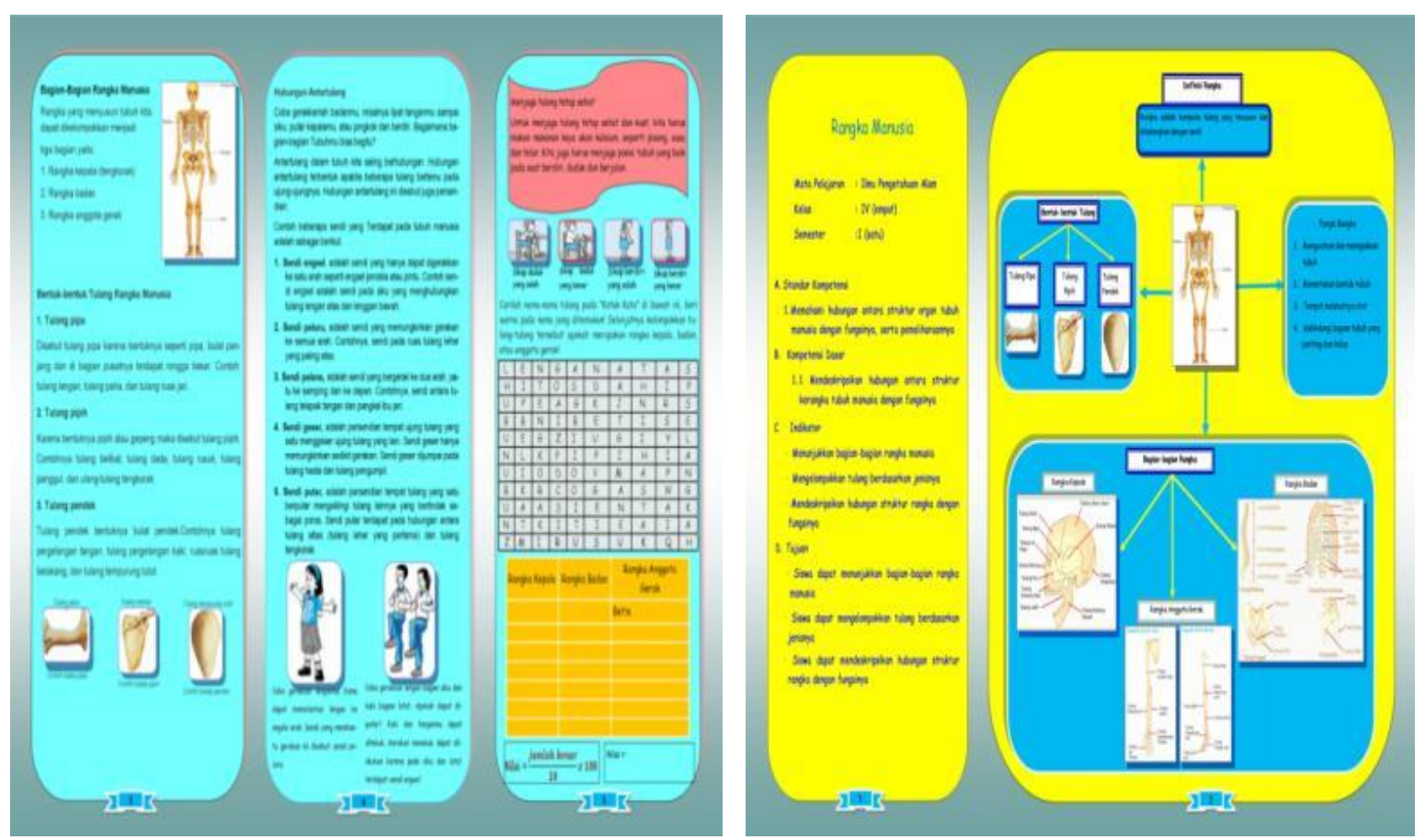

Gambar 7. Contoh Pamflet IPA 


\section{BAB III \\ PEMBAHASAN}

\section{A. Matriks Perbedaan Bahan Ajar Cetak}

Bahan ajar merupakan bagian penting dalam pelaksanaan pendidikan di sekolah. bahan ajar terbagi atas dua yaitu bahan ajar cetak dan bahan ajar non cetak. Bahan ajar cetak dapat diartikan sebagai seperangkat bahan yang memuat materi atau isi pelajaran untuk mencapai tujuan pembelajaran yang dituangkan dengan menggunakan teknologi cetak. Karakteristik bahan ajar cetak diantaranya pertama, mampu membelajarkan sendiri para siswa artinya siswa dapat aktif dalam proses pembelajaran. Kedua, bahan ajar cetak bersifat lengkap, artinya bahan ajar memuat hal-hal yang sangat diperlukan dalam proses pembelajaran.Bahan ajar cetak (printed) seperti antara lain handout, modul, buku, lembar kerja siswa dan pamflet. Agar pembaca mudah untuk memahaminya, berikut ini ditampilkan perbedaan dari masing-masing bahan ajar tersebut dalam bentuk tabel.

\begin{tabular}{|c|c|c|c|c|c|c|c|}
\hline Aspek & Handout & Modul & Diktat & Buku ajar & Buku teks & LKS & Pamflet \\
\hline Pengertian & $\begin{array}{l}\text { Bahan tertulis } \\
\text { yang } \\
\text { disiapkan } \\
\text { oleh seorang } \\
\text { guru untuk } \\
\text { memperkaya } \\
\text { pengetahuan } \\
\text { peserta didik. }\end{array}$ & $\begin{array}{l}\text { Modul adalah } \\
\text { satuan } \\
\text { program } \\
\text { pembelajaran } \\
\text { terkecil yang } \\
\text { dapat } \\
\text { dipelajari oleh } \\
\text { siswa secara } \\
\text { mandiri }\end{array}$ & $\begin{array}{l}\text { Diktat adalah } \\
\text { satu jenis cara } \\
\text { pengemasan } \\
\text { materi } \\
\text { pembelajaran } \\
\text { seperti buku } \\
\text { namun tidak } \\
\text { selengkap } \\
\text { buku }\end{array}$ & $\begin{array}{l}\text { Buku ajar } \\
\text { adalah buku } \\
\text { yang } \\
\text { digunakan } \\
\text { oleh siswa } \\
\text { mau-pun guru } \\
\text { dalam } \\
\text { kegiatan } \\
\text { belajar } \\
\text { mengajar. }\end{array}$ & $\begin{array}{l}\text { Buku teks } \\
\text { digunakan } \\
\text { sebagai sumber } \\
\text { dalam } \\
\text { mempelajari } \\
\text { kembali materi } \\
\text { yang telah } \\
\text { diajarkan dan } \\
\text { mempelajari } \\
\text { materi } \\
\text { selanjutnya. }\end{array}$ & $\begin{array}{l}\text { LKS merupakan } \\
\text { lembaran- } \\
\text { lembaran berisi } \\
\text { tugas yang harus } \\
\text { dikerja-kan oleh } \\
\text { siswa. }\end{array}$ & $\begin{array}{l}\text { Pamflet } \\
\text { berbentuk } \\
\text { selebaran yang } \\
\text { didalamnya berisi } \\
\text { tentang suatu } \\
\text { tulisan. }\end{array}$ \\
\hline
\end{tabular}




\begin{tabular}{|c|c|c|c|c|c|c|c|}
\hline Fungsi & $\begin{array}{l}\text { Handout } \\
\text { berfungsi } \\
\text { sebagai bahan } \\
\text { rujukan, } \\
\text { pemberi } \\
\text { motivasi, } \\
\text { pengingat, } \\
\text { pemberi } \\
\text { umpan balik, } \\
\text { dan menilai } \\
\text { hasil belajar. }\end{array}$ & $\begin{array}{l}\text { Modul } \\
\text { berfungsi } \\
\text { untuk } \\
\text { meningkatkan } \\
\text { motivasi } \\
\text { belajar siswa } \\
\text { secara } \\
\text { maksimal, } \\
\text { meningkatkan } \\
\text { kreativitas } \\
\text { guru dalam } \\
\text { mempersiap- } \\
\text { kan } \\
\text { pembelajaran, } \\
\text { mewujudkan } \\
\text { belajar yang } \\
\text { lebih } \\
\text { berkonsentrasi }\end{array}$ & $\begin{array}{l}\text { Diktat } \\
\text { berfungsi } \\
\text { untuk } \\
\text { membantu } \\
\text { proses belajar } \\
\text { yang bersifat } \\
\text { mandiri dan } \\
\text { memungkin- } \\
\text { kan variasi } \\
\text { bentuk cara } \\
\text { belajar, serta } \\
\text { meningkatkan } \\
\text { motivasi dan } \\
\text { prestasi } \\
\text { belajar. }\end{array}$ & $\begin{array}{l}\text { Buku ajar } \\
\text { bermuatan } \\
\text { nilai-nilai } \\
\text { karakter } \\
\text { diharapkan } \\
\text { memotivasi } \\
\text { siswa selama } \\
\text { belajar, } \\
\text { sehingga } \\
\text { pembelajaran } \\
\text { akan menarik } \\
\text { dan bermakna. }\end{array}$ & $\begin{array}{l}\text { Fungsi dari buku } \\
\text { teks adalah } \\
\text { sebagai bahan } \\
\text { referensi, } \\
\text { bahan evaluasi, } \\
\text { dan alat bantu } \\
\text { pendidik dalam } \\
\text { melaksanakan } \\
\text { kurikulum }\end{array}$ & $\begin{array}{l}\text { LKS berfungsi } \\
\text { untuk } \\
\text { memberikan } \\
\text { pengalaman } \\
\text { yang konkret } \\
\text { bagi siswa, } \\
\text { membantu } \\
\text { variasi belajar, } \\
\text { membangkit-kan } \\
\text { minat belajar } \\
\text { siswa, } \\
\text { meningkatkan } \\
\text { retensi belajar } \\
\text { mengajar, dan } \\
\text { memanfaatkan } \\
\text { waktu secara } \\
\text { efektif dan } \\
\text { efisien }\end{array}$ & $\begin{array}{l}\text { Fungsi pamflet } \\
\text { adalah sebagai } \\
\text { alat menyampai- } \\
\text { kan suatu pesan } \\
\text { atau informasi } \\
\text { kepada pembaca } \\
\text { mengenai sesuatu } \\
\text { hal }\end{array}$ \\
\hline $\begin{array}{l}\text { Struktur } \\
\text { penyusunan }\end{array}$ & $\begin{array}{l}\text { Struktur } \\
\text { penyusunan } \\
\text { handout } \\
\text { terdiri dari } \\
\text { identitas } \\
\text { handout, KI- } \\
\text { KD, materi } \\
\text { pokok, } \\
\text { soal/latihan, } \\
\text { dan sumber }\end{array}$ & $\begin{array}{l}\text { Struktur } \\
\text { penyusunan } \\
\text { modul terdiri } \\
\text { dari identitas, } \\
\text { petunjuk } \\
\text { belajar, KI- } \\
\text { KD, Materi } \\
\text { pembelajaran, } \\
\text { informasi } \\
\text { pendukung, }\end{array}$ & $\begin{array}{l}\text { Isi dari diktat } \\
\text { terdiri dari } \\
\text { pedoman } \\
\text { substansi yang } \\
\text { disusun } \\
\text { berdasarkan } \\
\text { kurikulum dan } \\
\text { silabus, dan } \\
\text { pedoman } \\
\text { format yang }\end{array}$ & $\begin{array}{l}\text { Struktur } \\
\text { penulisan } \\
\text { buku ajar } \\
\text { terdiri dari } \\
\text { halaman } \\
\text { pendahuluan, } \\
\text { halaman judul, } \\
\text { daftar isi, } \\
\text { daftar gambar, } \\
\text { kata }\end{array}$ & $\begin{array}{l}\text { Strukturpenyusu } \\
\text { nan buku teks } \\
\text { diantaranya } \\
\text { identitas, KI- } \\
\text { KD, materi } \\
\text { pelajaran, } \\
\text { materi, latihan } \\
\text { dan penilaian. }\end{array}$ & $\begin{array}{l}\text { Struktur LKS } \\
\text { terdiri dari } \\
\text { judul, petunjuk } \\
\text { belajar, } \\
\text { kompetensi } \\
\text { yang akan } \\
\text { dicapai, } \\
\text { informasi } \\
\text { pendukung, } \\
\text { tugas-tugas dan }\end{array}$ & $\begin{array}{l}\text { Struktur } \\
\text { pembuatan } \\
\text { pamflet dimulai } \\
\text { dari menentukan } \\
\text { pesan yang akan } \\
\text { disampaikan, } \\
\text { tambahkan } \\
\text { penjelasan } \\
\text { singkat, pilih } \\
\text { permintaan aksi, }\end{array}$ \\
\hline
\end{tabular}




\begin{tabular}{|l|l|l|l|l|l|l|}
\hline & bacaan. & $\begin{array}{l}\text { paparan isi } \\
\text { materi, latihan, } \\
\text { tugas/langkah } \\
\text { kerja, } \\
\text { penilaian. }\end{array}$ & $\begin{array}{l}\text { terdiri dari } \\
\text { bagian awal } \\
\text { dan bagian isi. }\end{array}$ & $\begin{array}{l}\text { pengantar, } \\
\text { kata sambutan, } \\
\text { halaman isi, } \\
\text { halaman } \\
\text { penutup }\end{array}$ & $\begin{array}{l}\text { menggunakan } \\
\text { bahasa yang } \\
\text { umum, dan } \\
\text { memisahkan teks } \\
\text { dan gambar }\end{array}$ \\
\hline
\end{tabular}

\section{B. Kelebihan dan Kekurangan Bahan Ajar Cetak}

Setelah melihat perbedaan dari handout, modul, buku, LKS dan pamflet, kita dapat melihat kelebihan dan kekurangan dari bahan ajar cetak tersebut. Kelebihan dari masing-masing bahan ajar cetak tentu berbeda-beda, dan kekurangan dari sebuah bahan ajar cetak perlu terus diperbaiki. Berikut ini kelebihan dan kekurangan bahan ajar cetak tersebut yang dibuatkan dalam bentuk tabel.

Tabel 2. Matriks Kelebihan dan Kekurangan Bahan Ajar Cetak.

\begin{tabular}{|c|c|c|c|}
\hline $\begin{array}{c}\text { Jenis Bahan } \\
\text { Ajar }\end{array}$ & Uraian/Kandungan & Kelebihan Bahan Ajar & Kelemahan Bahan Ajar \\
\hline 1. Handout & $\begin{array}{l}\text { Handout adalah bahan tertulis } \\
\text { yang siapkan oleh seorang guru } \\
\text { untuk memperkaya pengetahuan } \\
\text { peserta didik, termasuk pada } \\
\text { media ajar cetak. }\end{array}$ & $\begin{array}{l}\text { 1. Siswa dapat belajar sesuai dengan } \\
\text { kecepatan masing - masing } \\
\text { 2. Disamping dapat mengulang materi, } \\
\text { siswa dapat mengikuti urutan pikiran } \\
\text { secara logis } \\
\text { 3. Perpaduan teks dan gambar dapat } \\
\text { menambah daya tarik serta } \\
\text { memperlancar pemahaman informasi } \\
\text { yang disampaikan } \\
\text { 4. Lebih ekonomis dan mudah terdistribusi }\end{array}$ & $\begin{array}{l}\text { 1. Sulit menampilkan gerak dan } \\
\text { suara } \\
\text { 2. Bagian-bagian pelajaran harus } \\
\text { dirancang sedemikian rupa } \\
\text { 3. Cepat rusak atau hilang } \\
\text { 4. Umumnya kebehasilannya } \\
\text { hanya ditingkat kognitif }\end{array}$ \\
\hline 2. Modul & $\begin{array}{l}\text { Modul adalah bahan ajar yang } \\
\text { disusun secara sistematis dan }\end{array}$ & $\begin{array}{l}\text { Mengatasi keterbatasan waktu, ruang, } \\
\text { dan daya indera, baik siswa maupun }\end{array}$ & $\begin{array}{l}\text { 1. Kesukaran pada siswa tidak } \\
\text { segera dibatasi. }\end{array}$ \\
\hline
\end{tabular}




\begin{tabular}{|c|c|c|c|}
\hline & $\begin{array}{l}\text { menarik yang mencakup isi } \\
\text { materi, metode, dan evaluasi yang } \\
\text { dapat digunakan secara mandiri } \\
\text { untuk mencapai kompetensi yang } \\
\text { diharapkan. }\end{array}$ & $\begin{array}{l}\text { guru } \\
\text { 2. Dapat digunakan secara tepat dan } \\
\text { bervariasi, seperti untuk meningkatkan } \\
\text { motivasi belajar, mengembangkan } \\
\text { kemampuan dalam berinteraksi } \\
\text { langsung dengan lingkungan belajar. } \\
\text { 3. Memungkinkan siswa dapat mengukur } \\
\text { atau meengevaluasi sendiri hasil } \\
\text { belajarnya. } \\
\text { 4. Siswa lebih aktif belajar. } \\
\text { 5. Guru dapat berperan sebagai } \\
\text { pembimbing bukan semata-mata } \\
\text { sebagai pengajar. } \\
\text { 6. Membiasakan siswa untuk percaya pada } \\
\text { diri sendiri. } \\
\text { 7. Adanya kompetisi yang sehat antar } \\
\text { siswa. } \\
\text { 8. Dapat meringankan beban guru. } \\
\text { 9. Belajar lebih efektif dan evaluasi } \\
\text { perbaikan yang cukup berarti. } \\
\text { 10. Dapat menyerap perhatian anak } \\
\text { sehingga pelajaran menunjukkan lebih } \\
\text { berhasil apabila dibandingkan dengan } \\
\text { ceramah ( Vembrianto, 1981). }\end{array}$ & $\begin{array}{l}\text { 2. Tidak semua siswa dapat } \\
\text { belajar sendiri, melainkan } \\
\text { membutuhkan bantuan guru. } \\
\text { 3. Tidak semua bahan dapat } \\
\text { dimodulkan dan tidak semua } \\
\text { guru mengetahui cara } \\
\text { pelaksanaan pembelajaran } \\
\text { menggunakan modul. } \\
\text { 4. Kesukaran penyiapan bahan } \\
\text { dan memerlukan banyak biaya } \\
\text { dalam pembuatan modul. } \\
\text { 5. Adanya kecenderungan siswa } \\
\text { untuk tidak mempelajari modul } \\
\text { dengan baik (Vembrianto, } \\
\text { 1981). }\end{array}$ \\
\hline 3. Buku Teks & $\begin{array}{l}\text { Buku teks adalah buku pelajaran } \\
\text { yang disusun oleh para ahli atau } \\
\text { pakar dalam bidangnya untuk } \\
\text { menunjang program pengajaran }\end{array}$ & $\begin{array}{l}\text { 1. Buku teks dilengkapi dengan berbagai } \\
\text { data dan fakta disertai dengan gambar } \\
\text { yang aktual untuk membantu } \\
\text { memberikan motivasi kepada siswa }\end{array}$ & $\begin{array}{l}\text { 1. Buku teks yang dikembangkan } \\
\text { dari segi isi/materi masih perlu } \\
\text { ditambahkan dengan penemuan } \\
\text { data-data yang terbaru sebagai }\end{array}$ \\
\hline
\end{tabular}




\begin{tabular}{|c|c|c|c|}
\hline & $\begin{array}{l}\text { yang telah digariskan oleh } \\
\text { pemerintah. }\end{array}$ & $\begin{array}{l}\text { dalam memahami materi yang dimuat. } \\
\text { Posisi dari materi yang disandingkan } \\
\text { dengan berbagai gambar aktual } \\
\text { berfungsi untuk menciptakan kondisi } \\
\text { kontekstual dalam pelajaran. } \\
\text { 2. Buku teks yang dikembangkan dilihat } \\
\text { dari aspek kesesuaian dengan kaidah } \\
\text { kebahasaan, yaitu ketepatan dalam } \\
\text { pemilihan dan penempatan tanda baca, } \\
\text { pemilihan kata,serta penulisan sebuah } \\
\text { paragraf yang terintegrasi dengan yang } \\
\text { lainnya. Penggunaan istilah, penentuan } \\
\text { simbol serta struktur kalimat } \\
\text { disesuaikan dengan tingkat } \\
\text { perkembangan siswa. Hal ini dilakukan } \\
\text { untuk memudahkan siswa dalam } \\
\text { memahami materi bacaan dalam produk } \\
\text { yang dikembangkan. }\end{array}$ & $\begin{array}{l}\text { dasar pengembangan uraian. } \\
\text { Judul yang pertama diajukan } \\
\text { tidak kontekstual dengan materi } \\
\text { yang dikembangakn. Mengingat } \\
\text { pada silabus indikator, seperti } \\
\text { judul awal, maka pergantian } \\
\text { judul masih bisa dikondisikan. } \\
\text { 2. Buku teks ditinjau darisegi } \\
\text { bahasa, masih terdapat beberapa } \\
\text { kalimat yang panjang dengan } \\
\text { ide pokok yang kurang jelas. } \\
\text { Paragraf yang panjang maupun } \\
\text { terlalu pendek menjadikan } \\
\text { pokok pikiran pada paragraf } \\
\text { tersebut sulit untuk dikenali. }\end{array}$ \\
\hline 4. Buku Ajar & $\begin{array}{l}\text { Buku ajar adalah buku pegangan } \\
\text { untuk suatu mata pelajaran yang } \\
\text { ditulis dan disusun oleh pakar } \\
\text { bidang terkait dan memenuhi } \\
\text { kaidah buku teks serta diterbitkan } \\
\text { secara resmi dan disebar luaskan. }\end{array}$ & $\begin{array}{l}\text { 1. Di setiap sub terdapat target } \\
\text { pembelajaran sehingga baik siswa } \\
\text { maupun guru dapat mengetahui target } \\
\text { yang harus dicapai } \\
\text { 2. Terdapat daftar kosakata } \\
\text { 3. Terdapat pengantar tema di setiap bab. } \\
\text { 4. Tema serta materi yang terdapat didalam } \\
\text { buku cocok untuk siswa } \\
\text { 5. Bentuk latihan yang beragam. }\end{array}$ & $\begin{array}{l}\text { 1. Meskipun terdapat gambar } \\
\text { namun gambar yang tersaji } \\
\text { tidak menarik dan bentuk } \\
\text { tulisan yang digunakan terlihat } \\
\text { membosankan. } \\
\text { 2. Daftar kosa kata terdapat } \\
\text { bagian belakang buku sehingga } \\
\text { bagi pengguna buku tidak } \\
\text { efektif } \\
\text { 3. Penjelasan terhadap pola }\end{array}$ \\
\hline
\end{tabular}




\begin{tabular}{|c|c|c|}
\hline & & $\begin{array}{l}\text { kalimat yang digunakan kurang } \\
\text { jelas. } \\
\text { 4. Ukuran buku dirasa terlalu } \\
\text { besar }\end{array}$ \\
\hline 5. Diktat & $\begin{array}{l}\text { 1. Diktat dan pembelajaran merupakan dua } \\
\text { bentuk pengajaran yang berbeda dengan } \\
\text { pemanfaatan yang saling membantu; } \\
\text { 2. Diktat memungkinkan variasi bentuk } \\
\text { cara belajar dan meningkatkan motivasi } \\
\text { siswa; } \\
\text { 3. Diktat akan membantu proses beljar yang } \\
\text { bersifat mandiri suatu diktat } \\
\text { memudahkan siswa belajar mulai dari } \\
\text { awal semester; } \\
\text { 4. Dengan lebih dulu mempelajari diktat, } \\
\text { perhatikan siswa dalam pembelajaran } \\
\text { lebih dapat diarahkan ke materi } \\
\text { pembelajaran sehingga pelajaran dapat } \\
\text { dimengerti; } \\
\text { 5. Bentuk pelajaran dapat diubah sehingga } \\
\text { fungsi-fungsi pengajaran lainnya dapat } \\
\text { dipenuhi dengan lebih baik, misalnya } \\
\text { latihan, umpan balik; } \\
\text { 6. Siswa dapat mempersiapkan diri terlebih } \\
\text { dahulu sehingga komposisi siswa yang } \\
\text { mengikuti pembelajaran akan lebih } \\
\text { homogen. } \\
\text { 7. Diktat mendorong siswa untuk meninjau }\end{array}$ & \\
\hline
\end{tabular}




\begin{tabular}{|c|c|c|c|}
\hline & & $\begin{array}{l}\text { kembali apa yang telah dibahas dalam } \\
\text { pembelajaran. }\end{array}$ & \\
\hline 6. LKS & $\begin{array}{l}\text { Lembar Kerja Siswa (student } \\
\text { worksheet) adalah lembaran- } \\
\text { lembaran berisi tugas yang harus } \\
\text { dikerjakan oleh peserta didik. } \\
\text { Lembar kegiatan biasanya berupa } \\
\text { petunjuk dan langkah-langkah } \\
\text { untuk menyelesaikan suatu tugas }\end{array}$ & $\begin{array}{l}\text { 1. Dari aspek penggunaan } \\
\text { LKS merupakan media yang paling } \\
\text { mudah. Dapat dipelajari di mana saja dan } \\
\text { kapan saja tanpa harus menggunakan alat } \\
\text { khusus. } \\
\text { 2. Dari aspek pengajaran } \\
\text { Dibandingkan media pembelajaran jenis } \\
\text { lain, LKS bisa dikatakan lebih unggul. } \\
\text { Karena merupakan media yang baik } \\
\text { dalam mengembangkan kemampuan } \\
\text { siswa untuk belajar tentang fakta dan } \\
\text { mampu menggali prinsip-prinsip umum } \\
\text { dan abstrak dengan menggunakan } \\
\text { argumentasi yang realistis. } \\
\text { 3. Dari aspek kualitas penyampaian pesan } \\
\text { pembelajaran } \\
\text { LKS mampu memaparkan kata-kata, } \\
\text { angka-angka, notasi, gambar dua } \\
\text { dimensi, serta diagram dengan proses } \\
\text { yang sangat cepat. } \\
\text { 5. Dari aspek ekonomi } \\
\text { Secara ekonomis, LKS lebih murah } \\
\text { dibandingkan dengan media } \\
\text { pembelajaran yang lainnya. }\end{array}$ & $\begin{array}{l}\text { 1. Tidak mampu } \\
\text { mempresentasikan gerakan, } \\
\text { pemaparan materi bersifat } \\
\text { linear, tidak mampu } \\
\text { mempresentasikan kejadian } \\
\text { secara berurutan; } \\
\text { 2. Sulit memberikan bimbingan } \\
\text { kepada pembacanya yang } \\
\text { mengalami kesulitan memahmi } \\
\text { bagian-bagian tertentu; } \\
\text { 3. Sulit memberikan umpan balik } \\
\text { untuk pertanyaan yang diajukan } \\
\text { yang memiliki banyak } \\
\text { kemungkinan jawaban atau } \\
\text { pertanyaan yang membutuhkan } \\
\text { jawaban yang kompleks dan } \\
\text { mendalam; } \\
\text { 4. Tidak mengakomodasi siswa } \\
\text { dengan kemampuan baca } \\
\text { terbatas karena media ini ditulis } \\
\text { pada tingkat baca tertentu; } \\
\text { 5. Memerlukan pengetahuan } \\
\text { prasyarat agar siswa dapat } \\
\text { memahami materi yang } \\
\text { dijelaskan. Siswa yang tidak } \\
\text { memenuhi asumsi pengetahuan }\end{array}$ \\
\hline
\end{tabular}




\begin{tabular}{|c|c|c|c|}
\hline & & & $\begin{array}{l}\text { prasyarat ini akan mengalami } \\
\text { kesulitan dalam memahami; } \\
\text { 6. Cenderung digunakan sebagai } \\
\text { hafalan. Ada sebagaian guru } \\
\text { yang menuntut siswanya untuk } \\
\text { menghafal data, fakta dan } \\
\text { angka. Tuntutan ini akan } \\
\text { membatasi penggunaan hanya } \\
\text { untuk alat menghafal; } \\
\text { 7. Kadangkala memuat terlalu } \\
\text { banyak terminologi dan istilah } \\
\text { sehingga dapat menyebabkan } \\
\text { beban kognitif yang besar } \\
\text { kepada siswa; } \\
\text { 8. Presentasi satu arah karena } \\
\text { bahan ajar ini tidak interaktif } \\
\text { sehingga cendrung digunakan } \\
\text { dengan pasif, tanpa pemahaman } \\
\text { yang memadai. }\end{array}$ \\
\hline 7. Pamflet & $\begin{array}{l}\text { Pamflet adalah selebaran kertas } \\
\text { yang berukuran tidak tebal yang } \\
\text { didalamnya berisi tentang suatu } \\
\text { tulisan }\end{array}$ & $\begin{array}{l}\text { 1. Pamflet memiliki bentuk desain yang } \\
\text { unik sehingga pembaca menjadi lebih } \\
\text { menarik. } \\
\text { 2. Cakupan informasi yang dapat } \\
\text { dicantumkan dalam pamflet cukup luas. } \\
\text { 3. Menggunakan pamflet sebagai media } \\
\text { promosi cocok bagi Anda yang ingin } \\
\text { menggunakan metode "bercerita" dalam } \\
\text { promosi. }\end{array}$ & $\begin{array}{l}\text { 1. Dibutuhkan ketelitian dan } \\
\text { kesabaran dalam mendesain } \\
\text { pamflet. Hal ini disebabkan } \\
\text { karena penyajiannya yang pada } \\
\text { umumnya dilipat dengan } \\
\text { bentuk-bentuk tertentu } \\
\text { 2. Kesalahan desain dan } \\
\text { pengukuran dapat berakibat } \\
\text { fatal. }\end{array}$ \\
\hline
\end{tabular}




\section{BAB IV \\ PENUTUP}

\section{A. Kesimpulan}

Berdasarkan pembahasan tersebut, maka dapat disimpulkan sebagai berikut:

1. Bahan ajar cetak adalah segala sesuati informasi yang dapat dijadikan sebagai isi kurikulum yang dapat digunakan oleh peserta didik sesuai dengan kompetensi dasar yang dituangkan dalam bentuk tercetak seperti handout, modul, buku (diktat, buku ajar, buku teks), LKS dan pamflet

2. Karakteristik bahan ajar cetak adalah self instructional, self contained, dan self instruction material

3. Beberapa jenis bahan ajar cetak yaitu handout, modul, buku (diktat, buku ajar, buku teks), LKS dan pamflet

\section{B. Saran}

Penulis menyarankan kepada guru ataupun calon guru agar sebelum menyusun dan mengembangkan bahan ajar, hendaknya memahami peran, prinsip dan jenis bahan ajar cetak. 


\section{DAFTAR PUSTAKA}

Asrizal,A. dkk. (2013). "Pembuatan Modul Fisika Berbasis TIK Untuk Mengintegrasikan Nilai Pendidikan Karakter Dalam Pembelajaran Siswa SMAN 10 Padang Kelas X Semester 1". Jurnal Pillar Of Physics Education, Vol. 1. Hal. 30-38.

Asrizal,A. dkk. (2017). "Pengaruh Buku Ajar Bermuatan Kecerdasan Komprehensif dalam Model Pembelajaran Berbasis Masalah terhadap Kompetensi Fisika Peserta Didik Kelas X Sman 9 Padang”. Jurnal Pillar Of Physics Education, Vol. 9. Hal. 73-80

Asrizal, A. Festiyed,F. dkk. (2018). "Effectiveness of Integrated Science Instructional Material on Pressure in Daily Life Theme to Improvedigital Age Literacy Of Students". Journal of Physics: Conference Series. Hal 1-7. doi :10.1088/1742-6596/1006/1/012031

Agustina, Eka Sofia. (2011). Materi Ajar Telaah Buku Teks Bahasa Indonesia. Bahan Ajar Perkuliahan. Bandar Lampung: Universitas Lampung.

Amri, S. (2013). Pengembangan dan Model Pembelajaran dalam Kurikulum 2013. Jakarta: Prestasi Pustaka Publisher.

Buchori, A. (2015). "Development Learning Model of Character Education Through E-Comic in Elementary School." International Journal of Education and Research. ISSN 2411-5681. Vol. 3. No. 9. Hlm. 369-386.

Depdiknas. 2010. Panduang Pengembangan Bahan Ajar. Jakarta: Depdiknas.

Departemen Pendidikan Nasional. (2003). Sistem Pendidikan Nasional. Jakarta : Undang- Undang Republik Indonesia Nomor 20 Tahun 2003

Depdiknas. (2008). Panduan Pengembangan Bahan Ajar. Jakarta: Depdiknas.Depdiknas. 2007. Pedoman Memilih Menyusun Bahan Ajar dan Teks Mata Pelajaran. Jakarta: BP. Mitra Usaha Indonesia.

Febrianti, Erni, dkk. (2015). "Pengembanagan Lembar Kerja Siswa (LKS) Materi Larutan Penyangga Model Problem Based Learning Bermuatan Karakter" Journal of Innovative Science Education. ISSN 2252-6412. Vol. 1. No. 1. Hlm.1-9

Festiyed, Djusmaini Djamas. (2015). Modul Matakuliah Pengembangan Eveluasi dan Penilaian Proses Pembelajaran Fisika. Padang: Universitas Negeri Padang 
Festiyed,F.et all. (2018). "Effectiveness of Adaptive Contextual Learning Model of Integrated Science by Integrating Digital Age Literacy on Grade VIII Students". IOP Conference Series: Materials Science and Engineering. Hal 1-8. doi:10.1088/1757-899X/335/1/012067

Festiyed,F.et all. (2018). “The Development Of Integrated Science Instructional Materials To Improve Students Digital Literacy In Scientific Approach.”. Jurnal Pendidikan IPA Indonesia, Hal. 442-450. Vol 7, No, 4. DOI: 10. 15294/ JPII. V7i4. 13613.

Majid, Abdul. (2012). Perencanaan Pembelajaran Mengembangkan Standar Kompetensi Guru. Bandung: PT Remaja Rosda Karya.

Nugraha, Danu Aji. (2013). "Pengembanagan Bahan Ajar Reaksi Redoks Bervisi SETS dan Berorientasi Konstruktivistik." Journal of Innovative Science Education. ISSN 2252-6412. Vol. 2. No. 01. Hlm. 28-34.

Peraturan Pemerintah No. 32 Tahun 2013 Tentang Standar Nasional Pendidikan

Permendikbud Nomor 8 tahun 2016 Tentang Buku

Prastowo, Andi. (2011). Panduan Kreatif Membuat Bahan Ajar Inovatif. Yogyakarta: Diva Press.

Rizqiyah, Iffatur. (2018). "Species Rich of Spermatophyta in Paseban Parks Bangkalan Madura to Develop Discovery Model on the Material Handout Plantae." Journal of Innovative Science Education. e-ISSN 2502-4523. Vol. 7. No. 01. Hlm.69-77.

Sanjaya, Wina. (2008). Perencanaan dan desain sistem pembelajaran. Bandung: Prenada Media Group.

Setiyadi, Muhammad Wahyu, dkk. (2017). "Pengembanagan Modul Pembelajaran Biologi Berbasisi Pendekatan Saintifik Untuk Meningkatkan Hasil Belajar Siswat" Journal of Education Science and Technology. e-ISSN 2477-3840. Vol. 3. No. 2. Hlm.102-112.

Tarigan. H.G. (1986). Telaah Buku Teks Bahasa Indonesia. Bandung: Angkasa.

Umar, Hamalik. (2002). Perencanaan Pengajaran Berdasarkan Pendekatan Sistem. Jakarta: Bumi Aksara.

Vebrianto, ST. (1985). Pengantar Pengajaran Modul. Yogyakarta: Yayasan Pendidikan Paramita. 
Winkel. (2004). Psikologi Pembelajaran. Yogyakarta: PT. Media Abadi.

Yezita, Elva. dkk. (2012). "Mengkonstruksi Pengetahuan Siswa Pada Materi Segitiga dan Segiempat Menggunakan Bahan Ajar InterAktif Matematika Berbasis Konstruktivisme." Jurnal Pendidikan Matematika, Vol. 1. No. 1. Hlm. 54-59. 